\title{
Service Offshoring and the Skill Composition of Labor
}

\author{
Demand* \\ Rosario Crinò ${ }^{\dagger}$ \\ Institut d'Anàlisi Econòmica, CSIC
}

October 2009

\begin{abstract}
This paper studies the effects of service offshoring on the skill composition of labor demand, using novel comparable data for nine Western European countries between 1990 and 2004. The empirical analysis delivers three main results. First, service offshoring is skill-biased, because it increases the demand for high and medium skilled labor and decreases the demand for low skilled labor. Second, the effects of service offshoring are similar to those of material offshoring, both qualitatively and quantitatively. Third, the economic magnitude of these effects is not large.
\end{abstract}

JEL codes: F1.

Keywords: Offshoring; Labor Demand; Skills.

Word Count: 7,591

${ }^{*}$ I would like to thank Paolo Epifani and Anna Falzoni, as well as participants in the Aachen Workshop on International Production, ETSG (2008), IAE, IT\&FA (2008), KITeS, Unicredit Banca, the University of Bergamo and the University of Milan, for useful comments. Financial support from Unicredit Banca, the Barcelona GSE Research Network and the Generalitat de Catalunya is gratefully acknowledged. The usual disclaimer applies.

†Address: Institut d’Anàlisi Econòmica CSIC, Campus UAB, 08193 Bellaterra, Barcelona, Spain. E-mail: rosario.crino@iae.csic.es 


\section{Introduction}

Over the last decade, firms have moved an increasing number of service activities to foreign countries (Unctad, 2004; OECD, 2007), taking advantage of the sharp reduction in the cost of trading services induced by technological progress (Freund and Weinhold, 2002; Head et al., 2009). Consequently, the labor market implications of service offshoring have become an important concern in many industrialized economies (Amiti and Wei, 2005; Mankiw and Swagel, 2006). This paper aims to provide new empirical evidence on the much debated, but still controversial, issue of how service offshoring affects the skill composition of labor demand in these countries (The Economist, 2007). ${ }^{1}$

A priori, the effects of service offshoring on the skill composition of labor demand are not unambiguous. On the one hand, theoretical predictions based on factor proportion arguments suggest that the developed countries will specialize in skill-intensive services, and that relative labor demand will thus shift in favor of skilled workers as already occurred for the offshoring of production stages (material offshoring); see, in particular, Bhagwati et al. (2004), Deardorff (2005), Markusen (2005), Trefler (2005) and Markusen and Strand (2008). On the other hand, some empirical facts do not allow us to rule out the opposite result, namely that relative labor demand will shift away from skilled workers. In fact, many services are skill-intensive and are performed by highly educated individuals (Kirkegaard, 2004; Jensen and Kletzer, 2005); these services generally are more tradable than the low skill-intensive ones (Blinder, 2007; Jensen and Kletzer, 2008; Blinder and Krueger, 2009; Crinò, 2009b). ${ }^{2}$

This paper weighs in the debate and examines this issue using novel comparable data covering 20 manufacturing and service industries in nine Western European countries between 1990 and 2004. Information on employment and wages for three groups of high skilled, medium

\footnotetext{
${ }^{1}$ To clarify the terminology, this paper defines offshoring as the foreign relocation of activities through both foreign direct investment and arm's length contracts with unaffiliated parties (Helpman, 2006).

${ }^{2}$ Services are more tradable the more easily they can be transmitted electronically and the less face-to-face interaction they require with final consumers (see, e.g., Blinder, 2006; and Levy and Murname, 2006). Using a large sample of U.S. occupations, Blinder (2007) and Jensen and Kletzer (2008) find that the correlation between their educational level and proxies for their tradability is positive, ranging between 0.08 and 0.31 . Similarly, using individual-level data from the Princeton Data Improvement Initiative, Blinder and Krueger (2009) show that tradability increases rapidly with a worker's educational level, a finding confirmed by Crinò (2009b) for the U.S. white-collar occupations.
} 
skilled and low skilled workers, is obtained from the EUKLEMS data set. It is then matched with a service offshoring proxy, defined as the share of imported services in total non-energy input purchases (Amiti and Wei, 2005) and constructed using data from Eurostat.

The empirical analysis based on this data set consists of joint estimation of the system of labor demand functions derived from the cost minimization problem of a representative firm in each country and industry. Following Feenstra and Hanson $(1996,1999)$, we condition the optimization process on the service offshoring proxy, so that the labor demand functions experience parallel shifts when service offshoring changes. For our empirical application, we choose a translog representation for the cost function and estimate the implied system of wage bill share equations by Seemingly Unrelated Regressions.

Three main results emerge from the analysis. First, service offshoring is skill-biased, consistent with theoretical predictions based on factor proportion arguments. A rise in service offshoring, in fact, increases the demand for high and medium skilled labor and reduces the demand for low skilled labor. Second, the effects of service offshoring are qualitatively identical, and quantitatively similar, to those of material offshoring, as proxied by the share of imported intermediates in total non-energy input purchases (Feenstra and Hanson, 1996, 1999). Our preferred specification shows, in fact, that a 1 percent increase in service offshoring raises the wage bill share of high skilled labor by 0.04 percent and that of medium skilled labor by 0.06 percent, whereas it reduces the wage bill share of low skilled labor by 0.1 percent; the marginal effects of material offshoring are equal to $0.04,0.08$ and -0.12 percent, respectively. Third, the economic magnitude of the effects of service offshoring is not large. The cumulative increase in service offshoring over the sample period, in fact, explains 1 percent of the rise in the wage bill share of high skilled labor, 11 percent of the increase in the wage bill share of medium skilled labor and 3 percent of the decline in the wage bill share of low skilled labor; material offshoring accounts for an additional 1,21 and 5 percent, respectively.

These results successfully pass a large number of sensitivity checks. First, they are not driven by other factors potentially correlated with service offshoring, such as trade openness, quality of labor market institutions, productivity improvements and unobserved shocks at the 
country- and industry-level. Second, they do not depend on how the service offshoring proxy is constructed. Third, they remain unchanged when the main assumptions of the empirical model are relaxed, in particular when the potential endogeneity of service offshoring and the role of labor supply shifts and wage rigidities are taken into account.

This paper is related to the growing empirical literature on the labor market implications of service offshoring. It aims to contribute to this literature by shedding new light on the consequences for the skill composition of labor demand, which remain relatively unexplored. Most of the existing studies, in fact, focus on the effects of service offshoring on overall labor demand, convincingly showing that they are moderately negative in many developed countries; see, in particular, Amiti and Wei (2005), Görg and Hanley (2005), Hijzen and Swaim (2007), Hijzen et al. (2007), OECD (2007), Liu and Trefler (2008) and Blinder and Krueger (2009). To our knowledge, instead, contributions on the skill composition of labor demand are limited to Geishecker and Görg (2008a), who address this issue using micro-level wages for the U.K., and to Crinò (2009b), who uses industry-level data for the U.S.. This paper confirms the main finding of these studies, namely that service offshoring is skill-biased. However, it departs from them in two ways. First, it focuses on a larger set of countries, where service offshoring has grown rapidly over the last decade. Second, it studies the full response in labor demand, which usually brings about changes in relative employment along with those in relative wages. ${ }^{3}$

The paper is also related to the vast literature studying the effects of material offshoring on the skill composition of labor demand. In particular, it comes close to the empirical studies that use disaggregations of labor into more than two groups, such as Morrison and Siegel (2001), Falk and Koebel (2001, 2002), Ekholm and Hakkala (2005), Hijzen et al. (2005), Geishecker and Görg (2008b) and Becker et al. (2009). ${ }^{4}$ These works generally show that material offshoring is skilled biased, a result confirmed by this paper. However, none of them considers service offshoring. Borrowing the empirical framework proposed by these

\footnotetext{
${ }^{3}$ A parallel literature, both theoretical and empirical, studies other effects of service offshoring, such as those on wages and overall welfare (Samuelson, 2004; Antras et al., 2006; Baldwin, 2006; Baldwin and RobertNicoud, 2007; Rodriguez Clare, 2007; Grossman and Rossi-Hansberg, 2008), on productivity (Crinò, 2008; Görg et al., 2008; Amiti and Wei, 2009; Hijzen et al., 2009), and on innovation (Görg and Hanley, 2009).

${ }^{4}$ Recent and updated surveys of this literature can be found in Feenstra and Hanson (2003), Hijzen (2005) and Crinò (2009a).
} 
studies, this paper shows that the effects of service offshoring largely resemble those of material offshoring.

The remainder of the paper is organized as follows. Section (2) describes the data and contains some stylized facts; Section (3) explains the empirical model and the estimation strategy; Sections (4) and (5) present and discuss the results; Section (6) briefly concludes.

\section{Data and Stylized Facts}

\subsection{Data}

The data set includes nine Western European countries and, for each of them, contains information on 20 (NACE Rev. 2) manufacturing and service industries over the period 1990-2004. Table 1 reports the list of countries and industries, together with details on the coverage of the sample in the year 2004. The 20 industries account for more than 70 percent of private sector employment in each country; the nine economies, in turn, account for more than 75 percent of the EU-25 population (see Eurostat, 2004).

We retrieve data on a number of characteristics of the production process from EUKLEMS (Timmer et al., 2007), a large data set issued by a consortium of 14 European institutions within the Sixth EU Framework Program. EUKLEMS contains industry-level information (comparable across countries) on many variables including the following: gross output $(Y)$; total purchases of non-energy material and service inputs $(N E)$; total capital investment $(K)$; and the ICT share of capital investment $(I C T)$, a widely used proxy for technical progress (Berman et al., 1994; Feenstra and Hanson, 1999). It also contains data on hours worked $(E)$ and wage bill for three groups of workers: those with at least a bachelor's degree (defined as high skilled workers and indicated by $H$ ), those with either upper secondary or vocational education (medium skilled workers, $M$ ) and those with no formal qualification (low skilled workers, $L)$. We use this information to compute the average hourly wage rate $(W)$, employment share $(E s h)$ and wage bill share $(W s h)$ of each skill group. To pool the data

meaningfully across countries, we express the nominal figures in real terms and PPP using 
the industry-specific deflators provided by EUKLEMS. ${ }^{5}$

Following Amiti and Wei (2005), service offshoring is proxied by the share of imported private services in total non-energy input purchases. The underlying idea is simple: the output of the offshored services needs to be imported into Western Europe to enter the production process with other inputs; hence, the greater the intensity of service offshoring, the higher this indicator will be. The typical problem in constructing this proxy is the lack or limited disaggregation of service import data at the industry-level. Amiti and Wei (2005) therefore proposed to estimate these figures by combining Input-Output accounts with data on service imports at the economy-wide level. We follow the same approach to construct the main proxy for service offshoring used in this paper. ${ }^{6}$

From Eurostat, we gather economy-wide imports of 5 private services for the entire period of analysis: henceforth, $M_{s c t}$ will denote imports of service $s$ by country $c$ in year $t{ }^{7}$ Eurostat also publishes Input-Output accounts for two years, 1995 and $2000{ }^{8}$ To our purposes, an important element of the Input-Output accounts are the Import Matrixes, because they report detailed data on service and material imports for all the industries. Following Crinò (2009b), we use the Import Matrixes to compute the share of each industry $i$ in the economy-wide imports of the 5 services in 1995 and 2000. We call these shares $\vartheta_{\text {cis }}^{95}$ and $\vartheta_{\text {cis }}^{00}$, respectively, and average them out between the two years. Then, we multiply the resulting numbers, $\bar{\vartheta}_{c i s}$, by $M_{s c t}$. This provides us with an estimate of the imports of each service for all industries and years in the sample. Finally, we sum these figures across the 5 services to obtain the time

\footnotetext{
${ }^{5}$ Data for Sweden and the U.K. are converted to Euros using exchange rates from the 'International Financial Statistics' published by the International Monetary Fund.

${ }^{6}$ The lack of industry-level import data is also relevant for the construction of material offshoring proxies. The procedure proposed by Amiti and Wei (2005) is indeed inspired by Feestra and Hanson's (1996, 1999) method to estimate imported intermediate inputs for detailed industries.

${ }^{7}$ The 5 private services are: communication, finance and insurance, computer and information, royalties and licence fees, other business services. Data represent payments by European residents to both affiliated and unaffiliated foreign residents. Because most of the exchanges in these services occur between European firms and firms located abroad, payments to foreign residents provide a reliable measure of service imports (Bhagwati et al., 2004). Data for Sweden are unavailable prior to 1996.

${ }^{8}$ The Input-Output accounts adopt a common industrial classification (ESA95) and are thus comparable across countries. They are available for eleven Western European economies, but we must exclude Belgium and Denmark due to the lack of data on economy-wide service imports. For the U.K., Eurostat only publishes the accounts for 1995; those for 2000 are retrieved from STAN (OECD). For France, Eurostat publishes the accounts for 2000; those for 1995 are sourced from STAN.
} 
series of total service imports at the industry-level, $I M P S_{\text {cit }}$. Formally,

$$
I M P S_{c i t}=\sum_{s=1}^{5} \bar{\vartheta}_{c i s} \cdot M_{s c t} .
$$

The last step to obtain the proxy for service offshoring, $S O S$, consists of normalizing $I M P S$ using the total value of non-energy input purchases:

$$
S O S_{c i t}=\frac{I M P S_{c i t}}{N E_{c i t}}
$$

The use of inputs as the denominator of equation (1) makes $S O S$ comparable to the service offshoring proxies used by previous studies, e.g. Amiti and Wei (2005). However, this normalization has a potential drawback: if an industry substitutes its own production of services with imports, IMPS and $N E$ will increase by the same amount and $S O S$ will underestimate the change in service offshoring. In the spirit of Hijzen et al. (2005), robustness checks will thus be performed using industry output as an alternative normalization for $I M P S$; the corresponding proxy will be referred to as $S O S_{-} Y$.

An additional concern about $S O S$ may be raised by our procedure for estimating the numerator of equation (1). The construction of $I M P S$, in fact, is based on two assumptions that may cast some doubts on the ability of $S O S$ to be informative of the size and time behavior of service offshoring. First, the time variability of IMPS exclusively comes from the economy-wide service imports; second, its industry variability is maintained constant over the sample period. To ensure that the main results of this paper are not biased by measurement error, robustness checks will thus be performed using two alternative service offshoring proxies. The first, SOS_9500, applies $\vartheta^{95}$ to the imports for the period 1990-1999 and $\vartheta^{00}$ to those for more recent years. This indicator allows the industrial structure of service imports to change during the sample period, but requires some arbitrariness in the choice of the two time intervals. ${ }^{9}$ The second proxy, $S O S \_O F F$, directly uses the official information on industry-level service imports reported by the Import Matrixes, but can only be computed

\footnotetext{
${ }^{9}$ In any case, experimenting with alternative sub-periods did not lead to substantial changes in the qualitative results of this paper.
} 
for the years 1995 and 2000.

Finally, the Import Matrixes are combined with data on commodity imports from STAN to construct four equivalent proxies for material offshoring: $M O S, M O S \_Y, M O S_{-} 9500$ and MOS_OFF. ${ }^{10}$ Table A1 reports names, definitions, sources and descriptive statistics for all the variables used in the econometric analysis.

\subsection{Stylized Facts}

Table 2 contains descriptive statistics on the offshoring proxies, both for the whole sample of countries and for each country separately. Service offshoring is still a limited phenomenon in Western Europe, especially compared with material offshoring. However, service offshoring has increased over the sample period, both on average and across countries (with the exception of Austria); its growth rates were similar to, or higher than, those of material offshoring.

As expected, $S O S$ is higher than $S O S_{-} Y$ and tends to grow more slowly. It is also slightly higher than SOS_9500 and SOS_OFF, suggesting that the use of estimated imports may somewhat overstate the level of service offshoring. This difference, however, is driven by a single country, Austria, whereas for the other economies the three indicators are much closer to each other; similar conclusions apply to the material offshoring proxies. Despite these differences, the offshoring indicators are highly positively correlated among themselves: in particular, the correlation among the four service offshoring proxies averages out at 0.70 , and ranges between 0.56 and 0.82 ; similarly, the correlation between the four material offshoring proxies averages out at 0.83 , and ranges between 0.71 and 0.93 .

Turning to the labor market variables, Table 3 reports descriptive statistics on $W s h, E s h$ and the log real hourly wage rates of the three skill groups. Medium skilled workers make the lion's share (64 percent) of both employment and wage bill; high skilled workers and low skilled workers, on the other hand, account for 15 and 21 percent of total wage bill and for 10 and 26 percent of total employment. Over the sample period, the wage bill shares of high and medium skilled labor have increased by 55 and 7 percent, respectively, whereas the

\footnotetext{
${ }^{10}$ These indicators include intermediate inputs imported from all the industries, and therefore capture a broad concept of offshoring (Feenstra and Hanson, 1999).
} 
wage bill share of low skilled labor has plunged (-39 percent). These trends resulted from the combination of two factors: (1) an increase in the employment shares of high skilled workers and medium skilled workers; and (2) a widening of the wage gap between them and the low skilled, as evidenced by the faster increase in their real wages compared with those of low skilled workers.

Overall, these stylized fact show a contemporaneous increase in service offshoring and in the usage of more skilled labor in Western Europe, but they do not tell anything about causality. This issue is explored in the next sections.

\section{Empirical Model and Estimation Strategy}

As in the existing literature, our empirical approach is based on the following assumption: an easier access to service offshoring, due for instance to technological improvements, makes optimal for firms to adjust their domestic demand for workers with different educational levels. Under this assumption, the empirical model can be represented using a set of labor demand functions augmented by service offshoring; the latter acts as a shift-factor inducing parallel movements in the demand schedules.

We derive the demand functions for the three groups of workers from the cost minimization problem of a representative firm in each country and industry. ${ }^{11}$ Assume that the short-run cost function of this firm is

$$
\begin{gathered}
C_{S R}\left(W^{H}, W^{M}, W^{L}, Y, K, \mathbf{Z}^{\prime}\right)=\min _{E^{H}, E^{M}, E^{L}}\left(W^{H} \cdot E^{H}+W^{M} \cdot E^{M}+W^{L} \cdot E^{L}\right) \\
\text { s.t. } \quad Y=f\left(E^{H}, E^{M}, E^{L}, K, \mathbf{Z}^{\prime}\right)
\end{gathered}
$$

where $C_{S R}$ indicates short-run costs, i.e. total wage bill, and $\mathbf{Z}$ is a vector of shift-factors including service offshoring; country, industry and time subscripts are omitted to save on notation. ${ }^{12}$ Applying Shephard's lemma to equation (2) yields the demand functions for the

\footnotetext{
${ }^{11}$ See Morrison and Siegel (2001), Falk and Koebel (2001, 2002), Ekholm and Hakkala (2005) and Hijzen et al. (2005) for a similar approach.

${ }^{12}$ The use of a short-run representation for the cost function is dictated by the lack of data on the price of capital, which is therefore treated as a quasi-fixed input following Berman et al. (1994).
} 
three groups of workers:

$$
E^{r}=f\left(W^{H}, W^{M}, W^{L}, Y, K, \mathbf{Z}^{\prime}\right) \quad \forall r \in \mathbf{R} \equiv\{H, M, L\}
$$

Note that, similarly to Feenstra and Hanson $(1996,1999)$, the optimization problem is conditioned on service offshoring (and on the other shift-factors contained in the vector $\mathbf{Z}$ ). This means that firms choose employment optimally for a given level of this variable, and hence the labor demand functions depend on it. When service offshoring changes, firms will re-optimize over employment and the labor demand functions will experience a parallel shift.

To get the estimating version of (3), we start by assuming that the cost function has the following translog representation: ${ }^{13}$

$$
\begin{aligned}
\ln C_{S R}= & \alpha+\sum_{r \in \mathbf{R}} \beta_{r} \ln W^{r}+\beta_{Y} \ln Y+\beta_{K} \ln K+\sum_{z \in \mathbf{Z}} \beta_{z} z+ \\
& +\frac{1}{2}\left[\sum_{r \in \mathbf{R}} \sum_{v \in \mathbf{R}} \beta_{r, v} \ln W^{r} \cdot \ln W^{v}+\beta_{Y, Y}(\ln Y)^{2}+\beta_{K, K}(\ln K)^{2}+\sum_{z \in \mathbf{Z}} \sum_{q \in \mathbf{Z}} \beta_{z, q} z \cdot q\right]+ \\
& +\sum_{r \in \mathbf{R}} \beta_{r, Y} \ln W^{r} \cdot \ln Y+\sum_{r \in \mathbf{R}} \beta_{r, K} \ln W^{r} \cdot \ln K+\sum_{r \in \mathbf{R}} \sum_{z \in \mathbf{Z}} \beta_{r, z} \ln W^{r} \cdot z+ \\
& +\beta_{Y, K} \ln Y \cdot \ln K+\sum_{z \in \mathbf{Z}} \beta_{Y, z} \ln Y \cdot z+\sum_{z \in \mathbf{Z}} \beta_{K, z} \ln K \cdot z
\end{aligned}
$$

where linear price homogeneity and symmetry imply the following restrictions on the parameters:

$$
\begin{gathered}
\sum_{r \in \mathbf{R}} \beta_{r}=1 ; \sum_{r \in \mathbf{R}} \beta_{r, v}=\sum_{v \in \mathbf{R}} \beta_{v, r}=0 ; \sum_{r \in \mathbf{R}} \beta_{r, Y}=\sum_{r \in \mathbf{R}} \beta_{r, K}=\sum_{r \in \mathbf{R}} \beta_{r, z}=0 ; \\
\beta_{r, v}=\beta_{v, r} ; \beta_{z, q}=\beta_{q, z} .
\end{gathered}
$$

Then, we apply Shephard's lemma to (4) and obtain the following system of labor demand

\footnotetext{
${ }^{13}$ The elements of $\mathbf{Z}$ are not expressed in logs because the main shift-factors used in our analysis (service offshoring, material offshoring and technical progress) are all measured in percentages. In some of the robustness checks, the additional control variables will enter in logs; we will mention these cases when they occur.
} 
functions:

$$
W s h^{r}=\beta_{r}+\sum_{v \in \mathbf{R}} \beta_{r, v} \ln W^{v}+\beta_{r, Y} \ln Y+\beta_{r, K} \ln K+\sum_{z \in \mathbf{Z}} \beta_{r, z} z \quad \forall r \in \mathbf{R} .
$$

Note that, if $\beta_{r, S O S}>0(<0)$, a rise in service offshoring will move outward (inward) the demand function for the $r$-th group of workers and will increase (decrease) its wage bill share.

For theoretical consistency, the cost function must be concave in the wages of the three groups of workers. The necessary condition for concavity is that the Hessian matrix of the cost function, i.e. the matrix of wage elasticities, is negative semidefinite. This condition can be verified by testing that none of the own-wage elasticities are greater than zero. In the translog case, the own-wage elasticities are equal to

$$
\varepsilon^{r, r}=\frac{\beta_{r, r}}{W s h^{r}}+W s h^{r}-1 \quad \forall r \in \mathbf{R}
$$

and vary across observations because they are a combination of parameters and wage bill shares. Following the usual approach in the literature, these elasticities will thus be evaluated at the sample mean (Hijzen et al., 2005).

To the purpose of estimation, let $\mathbf{u} \equiv\left\{u^{H}, u^{M}, u^{L}\right\}$ denote a vector of additive disturbances for the system in (6) and assume that $\mathbf{u} \sim \mathbf{N}(0, \boldsymbol{\Sigma})$, where $\boldsymbol{\Sigma}=E\left(\mathbf{u}^{\prime} \mathbf{u}\right)$. Because the wage bill shares in (6) add up to one at each observation, the variance-covariance matrix $\boldsymbol{\Sigma}$ is singular. Hence, one equation must be dropped from the system to make estimation feasible. The estimated parameters are invariant with respect to the excluded equation if estimation is performed by Full Information Maximum Likelihood (FIML) or using Zellner's (1962) Iterated Seemingly Unrelated Regressions (ISUR). Although the two procedures yield asymptotically equivalent estimates (Berndt, 1991), ISUR is computationally simpler than FIML. We will thus estimate the parameters by ISUR (similarly to Ekholm and Hakkala, 2005; and Hijzen et al., 2005).

Dropping the equation for low skilled labor and imposing symmetry and linear price 
homogeneity restrictions according to (5) yields the estimating version of (6):

$$
\begin{aligned}
W s h^{H}= & \beta_{H}+\beta_{H, H} \ln \left(\frac{W^{H}}{W^{L}}\right)+\beta_{H, M} \ln \left(\frac{W^{M}}{W^{L}}\right)+ \\
& +\beta_{H, Y} \ln Y+\beta_{H, K} \ln K+\sum_{z \in \mathbf{Z}} \beta_{H, z} z+u^{H} \\
W s h^{M}= & \beta_{M}+\beta_{H, M} \ln \left(\frac{W^{H}}{W^{L}}\right)+\beta_{M, M} \ln \left(\frac{W^{M}}{W^{L}}\right)+ \\
& +\beta_{M, Y} \ln Y+\beta_{M, K} \ln K+\sum_{z \in \mathbf{Z}} \beta_{M, z} z+u^{M} .
\end{aligned}
$$

In order to wipe-out unobserved heterogeneity at the country-industry-level, the variables will be expressed in deviations from country-industry averages (Cornwell et al., 1992). ${ }^{14}$ Finally, the parameters not directly estimated from (7), i.e. $\beta_{H, L}, \beta_{M, L}$ and those of the low skilled labor equation, will be retrieved using the restrictions in (5) and their asymptotic standard errors will be computed using the delta method.

\section{Results}

\subsection{Main Estimates}

Table 4 reports the results from the estimation of (7). Panels a) and b) refer to a benchmark model including only SOS among the shift-factors (without and with year dummies, respectively). The coefficients of this variable are always precisely estimated at the 1 percent level; they are positive in the equations for high and medium skilled labor, and negative in the equation for low skilled labor. These very simple specifications therefore suggest that service offshoring shifts the demand for high and medium skilled labor outward and the demand for low skilled labor inward. Accordingly, it may have contributed to the rising usage of more skilled labor in Western Europe over the last decade.

Panel c) adds $M O S$ to the shift-factors. The coefficients of this variable are statistically significant at the 1 percent level; they are positive for high and medium skilled labor, and negative for low skilled labor. Consistent with previous studies, the effects of material off-

\footnotetext{
${ }^{14} \mathrm{An}$ alternative approach is to express the variables in first-differences. However, this may exacerbate bias due to measurement error in the data (Griliches and Hausman, 1986).
} 
shoring are therefore biased in favor of more skilled workers. The inclusion of MOS causes a slight reduction in the size of the coefficients of $S O S$, but does not change the main evidence emerged from the previous panels. Interestingly, the point estimates of the two offshoring proxies have a similar absolute dimension; indeed, the $F$-tests reported at the bottom of the table do not reject the null hypothesis that $\beta_{S O S}=\beta_{M O S}$ for any of the three skill groups.

In panel d), the specification also controls for $I C T$. This takes into account the effects of technical progress, which has been shown to be skill-biased (Berman et al., 1994) and may be correlated with service offshoring. In addition, including ICT makes the empirical model comparable with those estimated by previous studies, in particular by Feenstra and Hanson (1999). We therefore see panel d) as our preferred specification. Note that the coefficients of $I C T$ are always statistically significant and confirm that technical change favors more skilled workers. Importantly, controlling for technological progress does not alter the main results on service offshoring. The coefficients of $S O S$, in fact, show no change in their signs and significance, and remain close in size to those of MOS.

A quick look at the remaining estimates shows that none of the own-wage elasticities are statistically greater than zero. As regards output, its coefficients are always positive and very precisely estimated in the equation for high skilled labor, whereas they are generally negative and highly significant in the remaining cases. In line with previous studies, this suggests that the production technology is non-homothetic and that an increase in the scale of operations is biased in favor of high skilled labor (Epifani and Gancia, 2006, 2008). The capital coefficients, on the other hand, are always very small and, in our preferred specification, they are also quite imprecisely estimated. ${ }^{15}$

Overall, two main messages emerge from Table 4 regarding the effects of service offshoring. First, they are broadly consistent with theoretical predictions based on factor proportion arguments, which suggest that the developed countries should specialize in more skill-intensive services. Second, they are qualitatively identical, and quantitatively similar, to the effects of material offshoring. According to our preferred specification, in fact, a 1 percent increase in

\footnotetext{
${ }^{15}$ This may be due to the fact that capital investment is a poor proxy for the capital input. Hence, we also experimented using the capital stock, computed by the Perpetual Inventory Method with a depreciation rate of 7 percent and an initial stock equal to investment in 1970. The main results did not change.
} 
$S O S$ raises the wage bill shares of high and medium skilled labor by 0.04 and 0.06 percent, respectively, and reduces the wage bill share of low skilled labor by approximately 0.1 percent. These marginal effects are close in size to those of $M O S$, which are equal to $0.04,0.08$ and -0.12 percent. ${ }^{16}$ Section (5) will discuss what these numbers imply for the contributions of the two types of offshoring to the cumulative changes in the wage bill shares over the sample period. Before that, however, we submit our results to a number of sensitivity checks.

\subsection{Accounting for Concomitant Factors}

This section investigates whether the results are biased due to time-varying factors correlated with service offshoring but omitted from the specification. A first possibility is that service offshoring rises when countries become more integrated in international trade. In this case, $S O S$ could just be capturing the effect of trade openness, which should be skill-biased in skill-abundant economies. Hence, panel a) of Table 5 adds a control for trade openness to the system (7); this is defined as the log ratio between imports plus exports and GDP (ln OPEN) and is constructed using data from the 'World Development Indicators'. ${ }^{17}$ As expected, the coefficients of trade openness are positive and very precisely estimated in the equations for high and medium skilled labor, whereas they are negative and highly significant for low skilled labor. Nevertheless, adding this control does not produce any noteworthy change in the main results.

A second possibility is that service offshoring increases when the effectiveness of labor market institutions improves, because this may make domestic labor relatively more expensive. Panel b) controls for this issue by adding a time-varying proxy for the quality of labor market institutions in each country. This is defined as the log ratio between union membership and total employment $(\ln U N M E M B)$ and is constructed using Nickell's (2006) data for the period 1990-2000. Union membership favors low skilled workers at the expense of medium skilled employees, but controlling for it leaves the previous results almost unchanged.

\footnotetext{
${ }^{16}$ See Feenstra and Hanson (1999) for details on the interpretation of the coefficients.

${ }^{17}$ This variable is constructed at the country-level because trade data are unavailable for the service industries. It can be separately identified from the time dummies because there is enough cross-country variation in every year.
} 
A third possibility is that firms resort more to service offshoring when their production process becomes more input-intensive. If this change in technology also induced higher demand for more skilled labor, it would spuriously drive our results. To account for this issue, the system (7) is re-estimated including proxies for input-intensity, namely the log ratios between service and material purchases and total hours worked $(\ln S E R V I N T$ and $\ln M A T I N T$, respectively); these variables are constructed using data from EUKLEMS. The results are in panel c). Intermediate input intensity is associated with rising demand for high and medium skilled labor, whereas the opposite is true of service intensity. Apart from a slight reduction in the statistical significance of the coefficients, however, the main findings of this paper are preserved. ${ }^{18}$

A forth possibility is that service offshoring rises in industries enjoying positive productivity shocks, which in turn may be more likely to increase their demand for skilled workers. Panel d) therefore includes a proxy for productivity, defined as log value added per hour worked (ln $L A B P R O D)$ and computed using data from EUKLEMS. Reassuringly, our main conclusions are not driven by unobserved productivity shocks.

Finally, we try to account for other time-varying factors that either cannot be precisely measured or are entirely unobserved. To this purpose, panel e) adds the log price of energy in each country and industry (ln PEN, sourced from EUKLEMS) in order to control for macroeconomic shocks that cannot be measured in detailed industries, such as those induced by variations in oil prices. There is no substantial change in the main results. Instead, panel f) replaces the time dummies with full sets of interaction terms between five-year dummies and country effects and between five-year dummies and industry effects, so as to account for unobserved shocks at the country- and industry-level. Despite the substantial loss in degrees of freedom and the possible violation of concavity, the results are broadly consistent with the evidence discussed so far.

\footnotetext{
${ }^{18}$ We also experimented with a cost function including materials among the variable inputs. While the results are consistent with those reported in panel c), this alternative specification is less useful to our purposes. The estimated parameters, in fact, measure the effects of service offshoring on the variable-cost shares, which also include the expenditures in materials.
} 


\subsection{Relaxing the Model's Assumptions}

This section analyzes the robustness of the results when some of the main assumptions underlying the empirical analysis are relaxed. These sensitivity checks are reported in Table 6 , where we only focus on the shift-factors to save space.

Construction of the offshoring proxies Panels a)-c) replace $S O S$ and $M O S$ with alternative offshoring proxies. In particular, panel a) uses the indicators normalized by industry output $\left(S O S_{-} Y\right.$ and $\left.M O S_{-} Y\right)$, panel b) those based on Import Matrix coefficients for 1995 and 2000 (SOS_9500 and MOS_9500), and panel c) those based on official import data $\left(S O S_{-} O F F\right.$ and $\left.M O S_{-} O F F\right)$. Reassuringly, our findings do not crucially depend on how the offshoring proxies are constructed. Interestingly, the coefficients of service offshoring are slightly larger than those reported in Table 4 suggesting, if anything, that our preferred specification measures the lower bound of its effects.

Wage rigidities In rigid labor markets, relative wages do not immediately respond to a shift in labor demand. Rather, workers whose demand falls experience higher unemployment rates and the adjustment is mostly reflected by changes in relative employment (Freeman and Katz, 1995). To account for the possible non-fully-flexible nature of the labor markets in the nine economies, panel d) re-estimates the system (7) using employment shares as the dependent variables, following the approach suggested by Ekholm and Hakkala (2005) and Hijzen et al. (2005). Panels e) and f), instead, borrow from Berman et al. (1994) and re-estimate the wage bill share equations either using country-level wages or excluding the wage regressors altogether. ${ }^{19}$ The service offshoring coefficients maintain the same sign and approximately the same size as in Table 4 and, apart from one case, they remain statistically significant. Hence, the main evidence of this paper does not hinge on the assumptions underlying the functioning of the labor market.

\footnotetext{
${ }^{19}$ In panel e), we assume that the relative wages do not vary across the industries in a given country, whereas in panel f) we also assume that they do not vary across the nine economies. Note that this approach also partially accounts for the potential simultaneity of the relative wages in the system (7), an issue that is further explored later on.
} 
Labor supply shifts Our empirical model assumes that service offshoring works as a labor demand shifter. In principle, however, it may also be the firms' response to changes in labor supply: for instance, a declining supply of low skilled workers may induce firms to carry out more offshoring of low skill-intensive services. To ensure that the results are not biased by labor supply shifts, in panels g)-i) the system (7) is conditioned on three alternative proxies for the changes in labor supply: the growth rate of the number of hours worked $(\Delta E)$ and its first lag; the growth rate of $E s h^{H}$ and its first lag; country- and industry-specific time trends. The sign, size and significance of the coefficients remain largely unchanged, suggesting that our findings are not spuriously driven by labor supply shifts.

Simultaneity Until now, service offshoring has been treated as an exogenous technological parameter. In reality, however, it may be a choice variable that firms adjust together with relative labor demand. To account for this potential simultaneity, service offshoring is instrumented using its first two lags (as in Geishecker and Görg, 2008b) and the system (7) is re-estimated by Iterated Three-Stage Least Squares (I3SLS); the missing values generated by the lag operator are replaced with zeros as in Arellano and Bond (1991). The results are reported in panel $\mathrm{j}$ ). Note that the Hansen $J$-statistic for overidentifying restrictions is very low, suggesting that the instruments are uncorrelated with the error terms and hence valid. At the same time, Shea's (1997) partial $R^{2}$ and the $F$-statistic for excluded instruments are both very high, implying that the instruments are sufficiently correlated with the endogenous variable and hence relevant. ${ }^{20}$ Importantly, the estimates obtained by I3SLS are similar to those obtained by ISUR: this suggests that simultaneity is not a crucial issue for the main findings of this paper. ${ }^{21}$ The same conclusion is largely supported by the results in panel $\mathrm{k}$ ), where material offshoring and technical progress are instrumented, too, using their first and second lags. Finally, panel l) instruments all the explanatory variables with their first two

\footnotetext{
${ }^{20}$ The rule of thumb proposed by Staiger and Stock (1997) implies that the instruments are relevant if the $F$-statistic from first-stage regression is higher than 10 .

${ }^{21}$ The $C$-statistics obtained by estimating (7) equation-by-equation with Two-Stage Least Squares, equal $1.27(p$-value $=0.26)$ for high skilled labor and $1.75(p$-value $=0.19)$ for medium skilled labor. Hence, they never reject the exogeneity of service offshoring. This provides additional suggestive evidence in favor of the ISUR estimates.
} 
lags, in order to account also for the potential endogeneity of relative wages, output and capital. Although some caution is dictated in this case by the test for overidentifying restrictions, the main pattern of results is preserved.

\subsection{Other Issues}

We performed other sensitivity checks, which are not reported here due to space constraints. In particular, we estimated the system (7) separately on each country, in order to ensure that the average results do not hide substantial heterogeneity across the economies; restricted the estimation sample to the period 1997-2006, because service offshoring cannot be computed for Sweden in earlier years; weighted the regressions by the industry share of total input purchases, in order to account for possible heteroskedasticity in the error terms; used R\&D intensity as an alternative proxy for technical progress (as in Machin and Van Reenen, 1998). ${ }^{22}$ These robustness checks largely confirmed the main evidence discussed so far.

\section{Economic Magnitude}

This section quantifies the contribution of service offshoring to the shift towards more skilled labor documented in Section (2). To this purpose, it calculates how much of the change in the three wage bill shares is explained by the cumulative rise in service offshoring over the sample period. The calculation is performed by multiplying the estimates in Table 4, panel d), by the change in $S O S$ reported in Table 2 and then dividing the resulting numbers by the changes in the wage bill shares reported in Table 3; the standard errors are computed using the delta method.

The results are shown in Table 7 . Service offshoring explains 1 percent of the rise in the wage bill share of high skilled labor, 11 percent of the increase in the wage bill share of medium skilled labor, and 3 percent of the decline in the wage bill share of low skilled labor. The contributions of material offshoring, computed similarly, equal 1, 21 and 5 percent, whereas

\footnotetext{
${ }^{22}$ R\&D data were sourced from STAN. Because they are unavailable for Austria and for the wholesale and retail sectors of the other countries, we see R\&D intensity as a less reliable proxy for technological progress in our case.
} 
those of technical progress amount to 1, 5 and 2 percent. $^{23}$

One way to assess the quality of these results is to compare the contributions of material offshoring and technical progress with those reported by previous studies. This comparison is complicated, however, by differences in the empirical specification (Morrison and Siegel, 2001; Falk and Koebel, 2001, 2002) and in the procedure for computing the contributions (Ekholm and Hakkala, 2005; Hijzen et al., 2005). The closest work to this paper in terms of specification and calculation of the contributions is Feenstra and Hanson's (1999) study for the U.S.. We thus compare our results with those reported in that work. To this purpose, we first collect medium skilled workers and high skilled workers into a single group, in order to match the skill classification used by the authors. Then, we estimate the resulting relative labor demand function, which also corresponds to the main specification used by Feenstra and Hanson:

$$
W s h^{S}=\beta_{S}+\beta_{S, S} \ln \left(\frac{W^{S}}{W^{L}}\right)+\beta_{S, Y} \ln Y+\beta_{S, K} \ln K+\sum_{z \in \mathbf{Z}} \beta_{S, z} z+u^{S}
$$

where $S \equiv H+M$. As before, we control for a full set of year dummies and express the variables in deviations from country-industry averages.

The results are reported in Table 8. Column (1) contains the estimated parameters of equation (8): apart from capital, all of the estimates are statistically significant at the 1 percent level. The coefficients of SOS, MOS and ICT are all positive, suggesting that these variables shift relative skilled labor demand outward. As before, the marginal effects of service offshoring are similar in size to those of material offshoring. Column (2) reports the contributions of the three shift-factors: service offshoring explains approximately 9 percent of the rise in $W s h^{S}$, whereas material offshoring and technical progress account for 14 and 5 percent, respectively. ${ }^{24}$ For a meaningful comparison with Feenstra and Hanson's results, column (3) re-estimates equation (8) excluding service offshoring; the contributions of material offshoring and technical progress are reported in column (4). Note that the results are

\footnotetext{
${ }^{23}$ The increase in $I C T$ over the sample period is equal to 17.9 percent.

${ }^{24}$ The change in $W s h^{S}$ between 1990 and 2004 is equal to 14.5 percent.
} 
almost unchanged, apart from a slight increase in the effects of material offshoring. Columns

(5) contains the contributions implied by Feenstra and Hanson's estimates; they refer to a specification including the authors' broad proxy for material offshoring and the ICT share of capital investment. Note that material offshoring explains approximately 14 percent of the rise in the skilled labor share of wage bill in the U.S., whereas technological progress accounts for an additional 5 percent. These numbers are very close to our estimates.

\section{Conclusion}

This paper empirically studied the effects of service offshoring on the skill composition of labor demand, using novel comparable data for nine Western European countries between 1990 and 2004. Three main results emerged from the analysis. First, service offshoring is skill-biased, consistent with theoretical predictions based on factor proportion arguments. Second, its effects are qualitatively identical, and quantitatively similar, to those of material offshoring. Third, the economic magnitude of these effects is not large.

Taken together, the findings of this paper suggest that service offshoring should not call for new and specific schemes of government intervention. Its negative effects on low educated and poorly qualified workers, in fact, could be effectively tackled by the same combination of policies advocated against the adjustment costs of trade and material offshoring, and aimed at improving on-the-job training and access to secondary and tertiary education (OECD, 2005).

In conclusion, we mention a possible avenue for future research related to this paper. The speed and cost of adjustment to service offshoring may be different for individual employees, depending on their educational level and on other characteristics such as gender, race, occupation, labor market experience and geographical mobility. Understanding how these factors work may be crucial to designing and tailoring effective safety nets in the very short-run. While the present paper does not address such issues given its focus on aggregate effects, the studies on service offshoring using micro-level data are so far limited to a handful: among them are the recent contributions by Liu and Trefler (2008) and Blinder and Krueger (2009) for the U.S., and by Hijzen et al. (2007) and Geishecker and Görg (2008a) for the U.K.. The 
increasing availability of worker-level and matched employer-employee data sets will offer a great opportunity to expand the number and geographic coverage of these studies, thereby improving our understanding of the labor market implications of service offshoring in the developed countries.

\section{References}

[1] Amiti, M. and S.J. Wei, 2005, "Fear of Service Outsourcing: Is It Justified?," Economic Policy, 20(42), pp. 308-347

[2] Amiti, M. and S.J. Wei, 2009, "Service Offshoring and Productivity: Evidence from the US," The World Economy, 32(2), pp. 203-220

[3] Antras, P., L. Garicano and E. Rossi-Hansberg, 2006, "Offshoring in a Knowledge Economy," The Quarterly Journal of Economics, 121(1), pp. 31-77

[4] Arellano, M. and S. Bond, 1991, "Some Tests of Specification for Panel Data: Monte Carlo Evidence and an Application to Employment Equations", The Review of Economic Studies, 58(2), pp. 277-297

[5] Baldwin, R., 2006, "Globalization: The Great Unbundling(s)," Mimeo, Graduate Institute of International Studies, Geneva

[6] Baldwin, R. and F. Robert-Nicoud, 2007, "Offshoring: General Equilibrium Effects on Wages, Production and Trade," NBER Working Paper 12991

[7] Becker, S.O., K. Ekholm and M. Muendler, 2009, "Offshoring and the Onshore Composition of Tasks and Skills," CEPR Discussion Paper 7391

[8] Berman, E., J. Bound and Z. Griliches, 1994, "Changes in the Demand for Skilled Labor within U.S. Manufacturing: Evidence from the Annual Survey of Manufactures," The Quarterly Journal of Economics, 109(2), pp. 367-397 
[9] Berndt, E.R., 1991, The Practice of Econometrics, Classic and Contemporary, Reading, MA: Addison-Wesley

[10] Bhagwati, J., A. Panagariya and T.N. Srinivasan, 2004, "The Muddles over Outsourcing," The Journal of Economic Perspectives, 18(4), pp. 93-114

[11] Blinder, A.S., 2006, "Offshoring: The Next Industrial Revolution?," Foreign Affairs, March/April 2006, pp. 113-128

[12] Blinder, A.S., 2007, "How Many U.S. Jobs Might Be Offshorable?," CEPS Working Paper 142

[13] Blinder, A.S. and A.B. Krueger, 2009, "Alternative Measures of Offshorability: A Survey Approach," NBER Working Paper 15287

[14] Cornwell, C., P. Schmidt and D. Wyhowski, 1992, "Simultaneous Equations and Panel Data," Journal of Econometrics, 51(1-2), pp. 151-181

[15] Crinò, R., 2008, "Service Offshoring and Productivity in Western Europe," Economics Bulletin, 6(35), pp. 1-8

[16] Crinò, R., 2009a, "Offshoring, Multinationals and Labour Market: A Review of the Empirical Literature," Journal of Economic Surveys, 23(2), pp. 197-249

[17] Crinò, R., 2009b, "Service Offshoring and White-Collar Employment," The Review of Economic Studies, forthcoming

[18] Deardorff, A.V., 2005, "A Trade Theorist's Take on Skilled-Labor Outsourcing," International Review of Economics and Finance, 14(3), pp. 259-271

[19] Ekholm, K. and K. Hakkala, 2005, "The Effect of Offshoring on Labor Demand: Evidence from Sweden," CEPR Working Paper 5648

[20] Epifani, P. and G. Gancia, 2006, "Increasing Returns, Imperfect Competition, and Factor Prices," The Review of Economics and Statistics, 88(4), pp. 583-598 
[21] Epifani, P. and G. Gancia, 2008, "The Skill Bias of World Trade," The Economic Journal, 118(530), pp. 927-960

[22] Eurostat, 2004, "European Demography in 2003," available at http://epp.eurostat.ec.europa.eu/cache/ITY_PUBLIC/3-31082004-BP/EN/331082004-BP-EN.PDF

[23] Falk, M. and B.M. Koebel, 2001, "A Dynamic Heterogeneous Labour Demand Model for German Manufacturing," Applied Economics, 33(3), pp. 339-348

[24] Falk, M. and B.M. Koebel, 2002, "Outsourcing, Imports and Labour Demand," The Scandinavian Journal of Economics, 104(4), pp. 567-586

[25] Feenstra, R.C. and G.H. Hanson, 1996, "Globalization, Outsourcing and Wage Inequality," The American Economic Review, 86(2), pp. 240-245

[26] Feenstra, R.C. and G.H. Hanson, 1999, "The Impact of Outsourcing and High-Technology Capital on Wages: Estimates for the United States, 1979-1990," The Quarterly Journal of Economics, 114(3), pp. 907-940

[27] Feenstra, R.C. and G.H. Hanson, 2003, "Global Production Sharing and Rising Inequality: A Survey of Trade and Wages," in K. Choi and J. Harrigan (eds.) Handbook of International Economics, pp. 146-185, Basil Blackwell

[28] Freeman, R.B. and L.F. Katz, 1995, Differences and Changes in Wage Structures, NBER Comparative Labor Markets Series, Cambridge, MA

[29] Freund, C. and D. Weinhold, 2002, "The Internet and International Trade in Services," The American Economic Review, Papers and Proceedings, 92(2), pp. 236-240

[30] Geishecker, I. and H. Görg, 2008a, "Service Offshoring and Wages: Evidence from Micro Data," IZA Discussion Paper 3593 
[31] Geishecker, I. and H. Görg, 2008b, "'Winners and Losers: A Micro-Level Analysis of International Outsourcing and Wages," Canadian Journal of Economics, 41(1), pp. 243270

[32] Görg, H. and A. Hanley, 2005, "Labour Demand Effects of International Outsourcing: Evidence from Plant-Level Data," International Review of Economics and Finance, 14(3), pp. $365-376$

[33] Görg, H. and A. Hanley, 2009, "Services Outsourcing and Innovation: An Empirical Investigation," CEPR Discussion Paper 7390

[34] Görg, H., A. Hanley and E. Strobl, 2008, "Productivity Effects of International Outsourcing: Evidence from Plant-Level Data," Canadian Journal of Economics, 41(2), pp. $670-688$

[35] Griliches, Z. and J. Hausman, 1986, "Errors in Variables in Panel Data, Journal of Econometrics, 31(1), pp. 93-118

[36] Grossman, G.M. and E. Rossi-Hansberg, 2008, "Trading Tasks: A Simple Theory of Offshoring," The American Economic Review, 98(5), pp. 1978-1997

[37] Head, K., T. Mayer and J. Ries, 2008, "How Remote is the Offshoring Threat?," European Economic Review, 53(4), pp. 429-444

[38] Helpman, E., 2006, "Trade, FDI, and the Organization of Firms," Journal of Economic Literature, 44(4), pp. 580-630

[39] Hijzen, A., 2005, "A Bird's Eye View of International Outsourcing: Data, Measurement and Labour Demand Effects", Economie Internationale, 104(4), pp. 45-63

[40] Hijzen, A., H. Görg and R.C. Hine, 2005, "International Outsourcing and the Skill Structure of Labour Demand in the United Kingdom," The Economic Journal, 115(506), pp. 860-878 
[41] Hijzen, A., T. Inui and Y. Todo, 2009, "Does Offshoring Pay? Firm-Level Evidence from Japan," Economic Inquiry, forthcoming

[42] Hijzen, A., M. Pisu, R. Upward and P. Wright, 2007, "Employment, Job Turnover, and the Trade in Producer Services: Firm-Level Evidence," Research Paper 2007/37, Leverhulme Centre for Research on Globalization and Economic Policy, University of Nottingham

[43] Hijzen, A. and P. Swaim, 2007, "Does Offshoring Reduce Industry Employment?," Research Paper 2007/24, Leverhulme Centre for Research on Globalization and Economic Policy, University of Nottingham

[44] Jensen, B.J. and L. Kletzer, 2005, "Tradeable Services: Understanding the Scope and Impact of Services Offshoring," in L. Brainard and S.M. Collins (eds.) Offshoring WhiteCollar Work - The Issues and the Implications, pp. 73-133, Washington, D.C.: Brookings Trade Forum 2005

[45] Jensen, B.J. and L. Kletzer, 2008, "Measuring Tradeable Services and the Task Content of Offshorable Services Jobs," in K. Abraham, M. Harper and J. Spletzer (eds.) Labor in the New Economy, Chicago: University of Chicago Press

[46] Kirkegaard, J.F., 2004, "Outsourcing - Stains on the White-Collar?," Mimeo, Peterson Institute for International Economics, Washington D.C.

[47] Levy, F. and R. Murname, 2006, "How Computerized Work and Globalization Shape Human Skill Demands," Mimeo, Massachusetts Institute of Technology

[48] Liu, R. and D. Trefler, 2008, "Much Ado About Nothing: American Jobs and the Rise of Service Outsourcing to China and India," NBER Working Paper 14061

[49] Machin, S. and J. Van Reenen, 1998, "Technology and Changes in Skill Structure: Evidence from Seven OECD Countries," The Quarterly Journal of Economics, 113(4), pp. 1215-1244 
[50] Mankiw, G.N. and P. Swagel, 2006, "The Politics and Economics of Offshore Outsourcing," Journal of Monetary Economics, 53(5), pp. 1027-1056

[51] Markusen, J., 2005, "Modeling the Offshoring of White-Collar Services: From Comparative Advantage to the New Theories of Trade and FDI," in L. Brainard and S.M. Collins (eds.) Offshoring White-Collar Work - The Issues and the Implications, pp. 1-34, Washington, D.C.: Brookings Trade Forum 2005

[52] Markusen, J. and B. Strand, 2008, "Trade in Business Services in General Equilibrium," CEPR Discussion Paper 6080

[53] Morrison, C. and D. Siegel, 2001, "The Impacts of Technology, Trade and Outsourcing on Employment and Labor Composition," The Scandinavian Journal of Economics, 103(2), pp. $241-264$

[54] Nickell, W., 2006, "The CEP-OECD Institutions Data Set (1960-2004)," CEP Discussion Paper 759

[55] OECD, 2005, "Trade-Adjustment Costs in OECD Labour Markets: A Mountain or a Molehill?," OECD Employment Outlook, Paris and Washington, D.C.: OECD

[56] OECD, 2007, Offshoring and Employment: Trends and Impacts, Paris and Washington, D.C.: OECD

[57] Rodriguez Clare, A., 2007, "Offshoring in a Ricardian World," NBER Working Paper 13203

[58] Samuelson, P.A., 2004, "Where Ricardo and Mill Rebut and Confirm Arguments of Mainstream Economists Supporting Globalization," The Journal of Economic Perspectives, 18(3), pp. 135-146

[59] Shea, J., 1997, "Instrument Relevance in Multivariate Linear Models: A Simple Measure," The Review of Economics and Statistics, 79(2), pp. 348-352 
[60] Staiger, D. and J.H. Stock, 1997, "Instrumental Variables Regression with Weak Instruments," Econometrica, 65(3), 557-586

[61] Timmer, M., T. Van Moergastel, E. Stuivenwold, G. Ypma, M. O’Mahony and M. Kangasniemi, 2007, "EUKLEMS Growth and Productivity Accounts: Methodology (Part 1)," Mimeo, available at http://www.euklems.net/

[62] The Economist, 2007, "The Great Unbundling", January 18

[63] Trefler, D., 2005, "Offshoring: Threats and Opportunities," in L. Brainard and S.M. Collins (eds.) Offshoring White-Collar Work - The Issues and the Implications, pp. 3573, Washington, D.C.: Brookings Trade Forum 2005

[64] Unctad, 2004, World Investment Report: The Shift Towards Services, New York and Geneva: United Nations

[65] Zellner, A., 1962, "An Efficient Method of Estimating Seemingly Unrelated Regressions and Tests for Aggregation Bias," Journal of the American Statistical Association, 57(298), pp. $348-368$ 
Table 1 - Sample Composition and Coverage

\begin{tabular}{llll}
\hline \hline & & Industries & \\
\hline NACE Code & Description & NACE Code & Description \\
15,16 & Food, bev., tobac. & $30-33$ & Electrical, optical eqpmnt. \\
$17-19$ & Text., leath., footwear & 34,35 & Transport eqpmnt. \\
20 & Wood and cork & 36,37 & Manufacturing, nec \\
21,22 & Pulp, paper, print., publ. & 50 & Wholesale and retail, motor vehicles \\
23 & Coke, ref. petr. and nucl. fuel & 51 & Wholesale, except motor vehicles \\
24 & Chemicals & 52 & Retail, except motor vehicles \\
25 & Rubber and plastics & $60-63$ & Transportation and storage \\
26 & Other non metall. min. prod. & 64 & Post and telecommunication \\
27,28 & Basic metals and fabr. met. prod. & 70 & Real estate \\
29 & Machinery, nec & $71-74$ & Other business activities \\
\hline & & \\
\hline Countries & & \% of private sector employment in 2004 \\
Austria & & 75.0 \\
Finland & & 81.0 \\
France & & 79.0 \\
Germany & & 80.0 \\
Italy & & 77.0 \\
Netherlands & & 80.0 \\
Spain & & 70.0 \\
Sweden & & 82.0 \\
U.K. & & 77.0 \\
\hline Source: EUKLEMS. & \\
\hline
\end{tabular}

Source: EUKLEMS. 
Table 2 - Stylized Facts on Offshoring

\begin{tabular}{|c|c|c|c|c|c|c|c|c|c|c|c|c|}
\hline & Mean & 19990 & 1995 & 2000 & 2004 & $\begin{array}{c}\text { Change (90 } \\
04)\end{array}$ & Mean & 1990 & 1995 & 2000 & 2004 & $\begin{array}{c}\text { Change (90. } \\
04)\end{array}$ \\
\hline & \multicolumn{6}{|c|}{ Whole Sample } & \multicolumn{6}{|c|}{ Austria } \\
\hline SOS & 3.0 & 2.9 & 2.5 & 2.9 & 3.2 & 13.3 & 15.0 & 18.7 & 10.0 & 10.6 & 12.8 & -31.4 \\
\hline SOS_Y & 1.4 & 1.2 & 1.1 & 1.4 & 1.6 & 31.2 & 6.7 & 8.0 & 4.6 & 5.0 & 6.0 & -25.0 \\
\hline SOS_9500 & 2.1 & 1.7 & 1.8 & 2.2 & 2.5 & 52.3 & 3.2 & 3.8 & 2.8 & 2.5 & 3.0 & -20.9 \\
\hline SOS_OFF & 2.0 & - & 1.8 & 2.2 & - & - & 1.7 & - & 1.0 & 2.4 & - & - \\
\hline MOS & 22.1 & 19.9 & 21.8 & 23.9 & 23.4 & 17.6 & 40.4 & 38.2 & 40.9 & 40.0 & 36.7 & -3.9 \\
\hline MOS_Y & 12.6 & 11.3 & 12.3 & 13.8 & 13.5 & 19.5 & 21.5 & 19.9 & 21.9 & 21.9 & 19.7 & -1.4 \\
\hline MOS_9500 & 19.9 & 18.4 & 19.9 & 21.3 & 20.3 & 10.8 & 28.3 & 27.8 & 28.1 & 27.9 & 27.7 & -0.4 \\
\hline \multirow[t]{2}{*}{ MOS_OFF } & 19.1 & - & 18.8 & 19.4 & - & - & 16.7 & - & 16.4 & 17.1 & - & - \\
\hline & \multicolumn{6}{|c|}{ Finland } & \multicolumn{6}{|c|}{ France } \\
\hline sos & 2.7 & 3.1 & 3.2 & 3.2 & 2.7 & -12.0 & 0.9 & 0.7 & 0.8 & 0.8 & 0.9 & 19.0 \\
\hline SOS_Y & 1.1 & 1.1 & 1.5 & 1.4 & 1.1 & 5.9 & 0.4 & 0.3 & 0.4 & 0.4 & 0.4 & 52.9 \\
\hline SOS_9500 & 2.1 & 1.3 & 2.6 & 2.8 & 2.7 & 102.4 & 0.8 & 0.6 & 0.8 & 0.8 & 0.7 & 30.7 \\
\hline SOS_OFF & 3.2 & - & 3.1 & 3.2 & - & - & 0.9 & - & 1.0 & 0.9 & - & - \\
\hline MOS & 23.4 & 18.6 & 22.8 & 24.5 & 26.5 & 43.1 & 14.0 & 13.3 & 13.3 & 15.7 & 15.0 & 13.4 \\
\hline MOS_Y & 12.3 & 9.4 & 12.9 & 13.6 & 14.0 & 48.6 & 8.2 & 7.4 & 7.7 & 9.4 & 9.3 & 26.1 \\
\hline MOS_9500 & 19.6 & 15.6 & 20.2 & 20.7 & 22.5 & 44.5 & 13.3 & 13.3 & 13.5 & 15.9 & 12.0 & -9.8 \\
\hline \multirow[t]{2}{*}{ MOS_OFF } & 21.9 & - & 20.0 & 23.7 & - & - & 13.0 & - & 13.5 & 12.4 & - & - \\
\hline & \multicolumn{6}{|c|}{ Germany } & \multicolumn{6}{|c|}{ Italy } \\
\hline sos & 1.7 & 0.8 & 1.7 & 1.9 & 2.0 & 152.7 & 2.0 & 1.7 & 1.8 & 1.9 & 1.6 & -4.4 \\
\hline SOS_Y & 0.7 & 0.4 & 0.6 & 0.9 & 0.9 & 114.2 & 0.8 & 0.6 & 0.7 & 0.9 & 0.8 & 26.9 \\
\hline SOS_9500 & 1.8 & 1.5 & 1.7 & 2.0 & 2.1 & 39.8 & 1.6 & 1.4 & 1.4 & 1.6 & 1.4 & -4.0 \\
\hline SOS_OFF & 1.7 & - & 1.4 & 1.9 & - & - & 1.8 & - & 1.8 & 1.8 & - & - \\
\hline MOS & 16.0 & 15.4 & 14.3 & 18.7 & 17.5 & 13.7 & 18.9 & 16.5 & 20.6 & 20.2 & 18.4 & 11.4 \\
\hline MOS_Y & 8.6 & 7.2 & 7.8 & 10.2 & 9.8 & 34.8 & 10.3 & 9.0 & 10.5 & 11.8 & 11.2 & 24.1 \\
\hline MOS_9500 & 14.5 & 13.1 & 13.6 & 17.4 & 14.9 & 13.8 & 15.4 & 14.3 & 15.8 & 17.3 & 15.8 & 10.4 \\
\hline \multirow[t]{2}{*}{ MOS_OFF } & 16.1 & - & 15.0 & 17.2 & - & - & 18.2 & - & 18.7 & 17.6 & - & - \\
\hline & \multicolumn{6}{|c|}{ Netherlands } & \multicolumn{6}{|c|}{ Spain } \\
\hline sos & 4.1 & 2.8 & 3.0 & 4.3 & 6.1 & 118.9 & 1.9 & 1.1 & 1.8 & 2.2 & 2.5 & 129.9 \\
\hline SOS_Y & 2.0 & 1.3 & 1.5 & 2.2 & 3.0 & 132.0 & 0.9 & 0.5 & 0.8 & 1.2 & 1.3 & 172.0 \\
\hline SOS_9500 & 4.1 & 2.8 & 2.8 & 4.3 & 5.7 & 102.0 & 1.7 & 0.9 & 1.6 & 1.9 & 2.3 & 151.5 \\
\hline SOS_OFF & 2.8 & - & 2.4 & 3.3 & - & - & 2.0 & - & 1.6 & 2.5 & - & - \\
\hline MOS & 28.7 & 29.6 & 27.5 & 29.3 & 29.2 & -1.5 & 18.0 & 13.7 & 16.9 & 21.3 & 22.6 & 64.7 \\
\hline MOS_Y & 18.0 & 18.0 & 17.1 & 18.6 & 18.2 & 1.3 & 11.0 & 7.9 & 10.1 & 13.2 & 14.4 & 83.0 \\
\hline MOS_9500 & 27.9 & 30.2 & 27.5 & 25.3 & 26.1 & -13.6 & 16.6 & 12.5 & 15.7 & 19.8 & 20.8 & 65.7 \\
\hline \multirow[t]{2}{*}{ MOS_OFF } & 28.0 & - & 29.1 & 26.9 & - & - & 17.0 & - & 14.5 & 19.5 & - & - \\
\hline & \multicolumn{6}{|c|}{ Sweden } & \multicolumn{6}{|c|}{ U.K. } \\
\hline SOS & 2.6 & - & $0.9^{\mathrm{a}}$ & 3.0 & 3.3 & $277.7^{\mathrm{c}}$ & 1.5 & 0.9 & 0.9 & 1.7 & 2.1 & 121.5 \\
\hline SOS_Y & 1.5 & - & $0.5^{\mathrm{a}}$ & 1.7 & 1.8 & $279.5^{\mathrm{c}}$ & 0.6 & 0.4 & 0.4 & 0.8 & 0.9 & 138.5 \\
\hline SOS_9500 & 2.7 & & $0.9^{\mathrm{a}}$ & 2.8 & 3.6 & $318.5^{c}$ & 1.3 & 0.9 & 0.9 & 1.7 & 1.5 & 65.4 \\
\hline SOS_OFF & 2.4 & - & 1.8 & 3.0 & - & - & 1.4 & - & 1.7 & 1.2 & - & - \\
\hline MOS & 26.2 & $26.1^{\mathrm{b}}$ & 25.4 & 27.7 & 28.4 & $9.0^{\mathrm{d}}$ & 23.2 & 21.5 & 23.2 & 25.8 & 23.9 & 10.8 \\
\hline MOS_Y & 15.0 & $15.0^{\mathrm{b}}$ & 14.8 & 15.4 & 15.4 & $3.0^{\mathrm{d}}$ & 12.8 & 11.4 & 12.9 & 14.5 & 13.2 & 15.6 \\
\hline MOS_9500 & 23.9 & $23.7^{\mathrm{b}}$ & 23.2 & 24.2 & 24.7 & $4.0^{\mathrm{d}}$ & 21.4 & 20.0 & 22.2 & 24.1 & 20.2 & 1.0 \\
\hline MOS_OFF & 21.9 & - & 22.0 & 21.8 & - & - & 18.4 & - & 19.2 & 17.7 & - & - \\
\hline
\end{tabular}


Table 3 - Stylized Facts on Labor Market Variables

\begin{tabular}{|c|c|c|c|c|c|c|c|c|c|c|c|c|}
\hline \multirow[b]{4}{*}{$\mathrm{H}$} & \multicolumn{2}{|c|}{ Wsh } & \multicolumn{2}{|c|}{ Esh } & \multicolumn{2}{|c|}{$\ln W$} & \multicolumn{2}{|c|}{ Wsh } & \multicolumn{2}{|c|}{ Esh } & \multicolumn{2}{|c|}{$\ln W$} \\
\hline & Mean & $\begin{array}{l}\text { Change } \\
(90-04)\end{array}$ & Mean & $\begin{array}{l}\text { Change } \\
(90-04)\end{array}$ & Mean & $\begin{array}{l}\text { Change } \\
(90-04)\end{array}$ & Mean & $\begin{array}{l}\text { Change } \\
(90-04)\end{array}$ & Mean & $\begin{array}{l}\text { Change } \\
(90-04)\end{array}$ & Mean & $\begin{array}{l}\text { Change } \\
(90-04)\end{array}$ \\
\hline & \multicolumn{6}{|c|}{ Whole Sample } & \multicolumn{6}{|c|}{ Austria } \\
\hline & 15.0 & 54.6 & 9.8 & 59.8 & 3.3 & 67.0 & 9.4 & 80.0 & 6.3 & 90.6 & 3.3 & 51.9 \\
\hline M & 63.8 & 6.7 & 63.9 & 10.0 & 2.8 & 70.0 & 71.3 & 1.5 & 68.7 & 4.8 & 2.8 & 60.7 \\
\hline \multirow[t]{2}{*}{$\mathrm{L}$} & 21.2 & -38.8 & 26.3 & -33.4 & 2.5 & 47.8 & 19.3 & -28.6 & 25.0 & -24.6 & 2.5 & 58.4 \\
\hline & \multicolumn{6}{|c|}{ Finland } & \multicolumn{6}{|c|}{ France } \\
\hline $\mathrm{H}$ & 34.1 & 34.8 & 25.3 & 36.3 & 3.3 & 62.3 & 15.7 & 34.8 & 8.5 & 52.6 & 3.8 & 30.7 \\
\hline M & 39.8 & 14.9 & 44.7 & 19.3 & 2.9 & 59.4 & 61.5 & 9.2 & 62.3 & 18.0 & 3.1 & 42.5 \\
\hline \multirow[t]{2}{*}{$\mathrm{L}$} & 26.1 & -45.1 & 30.0 & -39.9 & 2.8 & 50.7 & 22.7 & -34.1 & 29.2 & -38.1 & 2.8 & 65.6 \\
\hline & \multicolumn{6}{|c|}{ Germany } & \multicolumn{6}{|c|}{ Italy } \\
\hline $\mathrm{H}$ & $12.1^{\mathrm{a}}$ & $38.0^{\mathrm{b}}$ & $6.6^{\mathrm{a}}$ & $28.5^{\mathrm{b}}$ & $3.8^{\mathrm{a}}$ & $69.8^{\mathrm{b}}$ & 4.8 & 88.8 & 5.0 & 49.3 & 3.3 & 67.8 \\
\hline M & $67.0^{\mathrm{a}}$ & $-2.3 b$ & $63.2^{\mathrm{a}}$ & $2.8^{\mathrm{b}}$ & $3.3^{\mathrm{a}}$ & $51.0^{\mathrm{b}}$ & 94.6 & -2.3 & 93.7 & -1.2 & 3.3 & 63.1 \\
\hline \multirow[t]{2}{*}{$\mathrm{L}$} & $20.9^{\mathrm{a}}$ & $-10.8 b$ & $30.2^{\mathrm{a}}$ & $-10.9 b$ & $2.8^{\mathrm{a}}$ & $61.8^{\mathrm{b}}$ & 0.6 & -80.0 & 1.3 & -53.4 & 2.4 & -34.5 \\
\hline & \multicolumn{6}{|c|}{ Netherlands } & \multicolumn{6}{|c|}{ Spain } \\
\hline $\mathrm{H}$ & 9.5 & 95.2 & 5.8 & 102.5 & 3.7 & 59.8 & 19.9 & 77.6 & 12.2 & 98.1 & 3.5 & 72.9 \\
\hline M & 82.0 & -0.9 & 82.7 & 2.8 & 3.1 & 60.1 & 28.7 & 47.7 & 27.9 & 59.4 & 3.0 & 77.9 \\
\hline \multirow[t]{2}{*}{$\mathrm{L}$} & 8.4 & -51.4 & 11.5 & -44.2 & 2.8 & 45.7 & 51.4 & -35.4 & 59.8 & -29.7 & 2.8 & 73.4 \\
\hline & \multicolumn{6}{|c|}{ Sweden } & \multicolumn{6}{|c|}{ U.K. } \\
\hline $\mathrm{H}$ & 12.3 & 50.6 & 8.3 & 69.2 & 1.3 & 23.9 & 17.0 & 86.2 & 10.2 & 116.4 & 3.9 & 89.4 \\
\hline M & 62.3 & 10.1 & 63.4 & 12.8 & 0.8 & 41.1 & 66.8 & 9.6 & 68.5 & 12.2 & 3.3 & 107.7 \\
\hline $\mathrm{L}$ & 25.3 & -38.2 & 28.3 & -37.3 & 0.7 & 40.0 & 16.2 & -58.8 & 21.3 & -49.1 & 3.0 & 76.4 \\
\hline
\end{tabular}


Table 4 - Main Estimates

Dependent Variables: Wage Bill Shares of High Skilled (H), Medium Skilled (M) and Low Skilled (L) Workers

\begin{tabular}{|c|c|c|c|c|c|c|c|c|c|c|c|c|}
\hline & \multicolumn{3}{|l|}{ a) Baseline } & \multicolumn{3}{|c|}{ b) Adding Year Dummies } & \multicolumn{3}{|c|}{ c) Adding MOS } & \multicolumn{3}{|c|}{ "d) Adding ICT } \\
\hline & $\mathrm{H}$ & $\mathrm{M}$ & $\mathrm{L}$ & $\mathrm{H}$ & $\mathrm{M}$ & $\mathrm{L}$ & $\mathrm{H}$ & $\mathrm{M}$ & $\mathrm{L}$ & $\mathrm{H}$ & $\mathrm{M}$ & $\mathrm{L}$ \\
\hline $\ln \mathrm{W}^{\mathrm{H}}$ & $\begin{array}{l}0.131^{* * *} \\
{[0.005]}\end{array}$ & $\begin{array}{l}-0.132 * * * \\
{[0.005]}\end{array}$ & $\begin{array}{l}0.001 \\
{[0.003]}\end{array}$ & $\begin{array}{l}0.134^{* * *} \\
{[0.005]}\end{array}$ & $\begin{array}{l}-0.151 * * * \\
{[0.005]}\end{array}$ & $\begin{array}{l}0.017 * * * \\
{[0.003]}\end{array}$ & $\begin{array}{l}0.134^{* * * *} \\
{[0.005]}\end{array}$ & $\begin{array}{l}-0.150^{* * *} \\
{[0.005]}\end{array}$ & $\begin{array}{l}0.016^{* * *} \\
{[0.003]}\end{array}$ & $\begin{array}{l}0.134 * * * \\
{[0.005]}\end{array}$ & $\begin{array}{l}-0.150^{* * *} \\
{[0.005]}\end{array}$ & $\begin{array}{l}0.016 * * * \\
{[0.003]}\end{array}$ \\
\hline $\ln \mathrm{W}^{\mathrm{M}}$ & $\begin{array}{l}-0.132 * * * \\
{[0.005]}\end{array}$ & $\begin{array}{l}0.121^{* * *} \\
{[0.006]}\end{array}$ & $\begin{array}{l}0.010 * * \\
{[0.004]}\end{array}$ & $\begin{array}{l}-0.151 * * * \\
{[0.005]}\end{array}$ & $\begin{array}{l}0.122 * * * \\
{[0.006]}\end{array}$ & $\begin{array}{l}0.029 * * * \\
{[0.004]}\end{array}$ & $\begin{array}{l}-0.150 * * * \\
{[0.005]}\end{array}$ & $\begin{array}{l}0.123 * * * \\
{[0.006]}\end{array}$ & $\begin{array}{l}0.027 * * * \\
{[0.004]}\end{array}$ & $\begin{array}{l}-0.150 * * * \\
{[0.005]}\end{array}$ & $\begin{array}{l}0.123 * * * \\
{[0.006]}\end{array}$ & $\begin{array}{l}0.027^{* * * *} \\
{[0.004]}\end{array}$ \\
\hline $\ln \mathrm{W}^{\mathrm{L}}$ & $\begin{array}{l}0.001 \\
{[0.003]}\end{array}$ & $\begin{array}{l}0.010^{* *} \\
{[0.004]}\end{array}$ & $\begin{array}{l}-0.011^{* *} \\
{[0.006]}\end{array}$ & $\begin{array}{l}0.017^{* * *} \\
{[0.003]}\end{array}$ & $\begin{array}{l}0.029 * * * \\
{[0.004]}\end{array}$ & $\begin{array}{l}-0.046 * * * \\
{[0.005]}\end{array}$ & $\begin{array}{l}0.016^{* * * *} \\
{[0.003]}\end{array}$ & $\begin{array}{l}0.027^{* * *} \\
{[0.004]}\end{array}$ & $\begin{array}{l}-0.043^{* * *} \\
{[0.004]}\end{array}$ & $\begin{array}{l}0.016^{* * * *} \\
{[0.003]}\end{array}$ & $\begin{array}{l}0.027 * * * \\
{[0.004]}\end{array}$ & $\begin{array}{l}-0.043^{* * * *} \\
{[0.004]}\end{array}$ \\
\hline sos & $\begin{array}{l}0.084^{* * *} \\
{[0.021]}\end{array}$ & $\begin{array}{l}0.062 * * * \\
{[0.024]}\end{array}$ & $\begin{array}{l}-0.146 * * * \\
{[0.034]}\end{array}$ & $\begin{array}{l}0.053^{* * *} \\
{[0.017]}\end{array}$ & $\begin{array}{l}0.082^{* * *} \\
{[0.022]}\end{array}$ & $\begin{array}{l}-0.135^{* * *} \\
{[0.027]}\end{array}$ & $\begin{array}{l}0.042 * * \\
{[0.017]}\end{array}$ & $\begin{array}{l}0.057 * * * \\
{[0.022]}\end{array}$ & $\begin{array}{l}-0.099 * * * \\
{[0.027]}\end{array}$ & $\begin{array}{l}0.041^{* *} \\
{[0.017]}\end{array}$ & $\begin{array}{l}0.056^{* * *} \\
{[0.022]}\end{array}$ & $\begin{array}{l}-0.097 * * * \\
{[0.027]}\end{array}$ \\
\hline MOS & & & & & & & $\begin{array}{l}0.038^{* * *} \\
{[0.009]}\end{array}$ & $\begin{array}{l}0.082^{* * *} \\
{[0.011]}\end{array}$ & $\begin{array}{l}-0.120^{* * *} \\
{[0.014]}\end{array}$ & $\begin{array}{l}0.036^{* * *} \\
{[0.009]}\end{array}$ & $\begin{array}{l}0.081^{* * *} \\
{[0.011]}\end{array}$ & $\begin{array}{l}-0.117^{* * *} \\
{[0.014]}\end{array}$ \\
\hline ICT & & & & & & & & & & $\begin{array}{l}0.023^{* * *} \\
{[0.009]}\end{array}$ & $\begin{array}{l}0.019 * \\
{[0.011]}\end{array}$ & $\begin{array}{l}-0.042^{* * *} \\
{[0.014]}\end{array}$ \\
\hline $\ln \mathrm{Y}$ & $\begin{array}{l}0.095^{* * *} \\
{[0.003]}\end{array}$ & $\begin{array}{l}0.020^{* * *} \\
{[0.004]}\end{array}$ & $\begin{array}{l}-0.114 * * * \\
{[0.005]}\end{array}$ & $\begin{array}{l}0.037 * * * \\
{[0.003]}\end{array}$ & $\begin{array}{l}-0.023 * * * \\
{[0.004]}\end{array}$ & $\begin{array}{l}-0.013 * * * \\
{[0.005]}\end{array}$ & $\begin{array}{l}0.041^{* * *} \\
{[0.003]}\end{array}$ & $\begin{array}{l}-0.015^{* * *} \\
{[0.004]}\end{array}$ & $\begin{array}{l}-0.026 * * * \\
{[0.005]}\end{array}$ & $\begin{array}{l}0.039 * * * \\
{[0.003]}\end{array}$ & $\begin{array}{l}-0.016 * * * \\
{[0.004]}\end{array}$ & $\begin{array}{l}-0.023^{* * *} \\
{[0.005]}\end{array}$ \\
\hline $\ln \mathrm{K}$ & $\begin{array}{l}0.003^{* *} \\
{[0.001]}\end{array}$ & $\begin{array}{l}0.012 * * * \\
{[0.002]}\end{array}$ & $\begin{array}{l}-0.016^{* * *} \\
{[0.002]}\end{array}$ & $\begin{array}{l}-0.004 * * * \\
{[0.001]}\end{array}$ & $\begin{array}{l}0.004^{* * *} \\
{[0.001]}\end{array}$ & $\begin{array}{l}0.000 \\
{[0.002]}\end{array}$ & $\begin{array}{l}-0.003^{* * *} \\
{[0.001]}\end{array}$ & $\begin{array}{l}0.004^{* * *} \\
{[0.001]}\end{array}$ & $\begin{array}{l}-0.001 \\
{[0.002]}\end{array}$ & $\begin{array}{l}-0.002 \\
{[0.001]}\end{array}$ & $\begin{array}{l}0.006 * * * \\
{[0.002]}\end{array}$ & $\begin{array}{l}-0.004^{*} \\
{[0.002]}\end{array}$ \\
\hline Own-wage elasticity & $\begin{array}{l}0.020 \\
{[0.032]}\end{array}$ & $\begin{array}{l}-0.172^{* * *} \\
{[0.010]}\end{array}$ & $\begin{array}{l}-0.840 * * * \\
{[0.027]}\end{array}$ & $\begin{array}{l}0.039 \\
{[0.030]}\end{array}$ & $\begin{array}{l}-0.171 * * * \\
{[0.010]}\end{array}$ & $\begin{array}{l}-1.004^{* * *} \\
{[0.021]}\end{array}$ & $\begin{array}{l}0.040 \\
{[0.030]}\end{array}$ & $\begin{array}{l}-0.170 * * * \\
{[0.010]}\end{array}$ & $\begin{array}{l}-0.992 * * * \\
{[0.021]}\end{array}$ & $\begin{array}{l}0.042 \\
{[0.030]}\end{array}$ & $\begin{array}{l}-0.169 * * * \\
{[0.010]}\end{array}$ & $\begin{array}{l}-0.991 * * * \\
{[0.021]}\end{array}$ \\
\hline$F$-test $\mathrm{H}_{0}: \beta_{\text {Sos }}=\beta_{\text {MOS }}(p$-value $)$ & - & - & - & - & - & - & 0.84 & 0.33 & 0.51 & 0.82 & 0.33 & 0.53 \\
\hline Obs. & & 2357 & & & 2357 & & & 2357 & & & 2357 & \\
\hline Generalized R² & & 0.71 & & & 0.85 & & & 0.85 & & & 0.85 & \\
\hline
\end{tabular}


Table 5 - Accounting for Concomitant Factors

Dependent Variables: Wage Bill Shares of High Skilled (H), Medium Skilled (M) and Low Skilled (L) Workers

\begin{tabular}{|c|c|c|c|c|c|c|c|c|c|}
\hline & \multicolumn{3}{|c|}{ a) Adding Trade Opennes } & \multicolumn{3}{|c|}{ b) Adding Union Membership } & \multicolumn{3}{|c|}{ c) Adding Mat.- and Serv.- Intensity } \\
\hline & $\mathrm{H}$ & $\mathrm{M}$ & $\mathrm{L}$ & $\mathrm{H}$ & $\mathrm{M}$ & $\mathrm{L}$ & $\mathrm{H}$ & M & $\mathrm{L}$ \\
\hline $\ln \mathrm{W}^{\mathrm{H}}$ & $\begin{array}{l}0.134 * * * \\
{[0.005]}\end{array}$ & $\begin{array}{l}-0.149 * * * \\
{[0.005]}\end{array}$ & $\begin{array}{l}0.015^{* * *} \\
{[0.003]}\end{array}$ & $\begin{array}{l}0.119 * * * \\
{[0.005]}\end{array}$ & $\begin{array}{l}-0.137 * * * \\
{[0.006]}\end{array}$ & $\begin{array}{l}0.018 * * * \\
{[0.003]}\end{array}$ & $\begin{array}{l}0.134 * * * \\
{[0.004]}\end{array}$ & $\begin{array}{l}-0.147 * * * \\
{[0.005]}\end{array}$ & $\begin{array}{l}0.013^{* * *} \\
{[0.003]}\end{array}$ \\
\hline $\ln \mathrm{W}^{\mathrm{M}}$ & $\begin{array}{l}-0.149 * * * \\
{[0.005]}\end{array}$ & $\begin{array}{l}0.124 * * * \\
{[0.006]}\end{array}$ & $\begin{array}{l}0.026 * * * \\
{[0.004]}\end{array}$ & $\begin{array}{l}-0.137 * * * \\
{[0.006]}\end{array}$ & $\begin{array}{l}0.106^{* * * *} \\
{[0.008]}\end{array}$ & $\begin{array}{l}0.031^{* * *} \\
{[0.005]}\end{array}$ & $\begin{array}{l}-0.147 * * * \\
{[0.005]}\end{array}$ & $\begin{array}{l}0.122 * * * \\
{[0.006]}\end{array}$ & $\begin{array}{l}0.025^{* * *} \\
{[0.004]}\end{array}$ \\
\hline $\ln \mathrm{W}^{\mathrm{L}}$ & $\begin{array}{l}0.015^{* * *} \\
{[0.003]}\end{array}$ & $\begin{array}{l}0.026 * * * \\
{[0.004]}\end{array}$ & $\begin{array}{l}-0.041^{* * *} \\
{[0.004]}\end{array}$ & $\begin{array}{l}0.018 * * * \\
{[0.003]}\end{array}$ & $\begin{array}{l}0.031 * * * \\
{[0.005]}\end{array}$ & $\begin{array}{l}-0.049 * * * \\
{[0.006]}\end{array}$ & $\begin{array}{l}0.013^{* * *} \\
{[0.003]}\end{array}$ & $\begin{array}{l}0.025^{* * *} \\
{[0.004]}\end{array}$ & $\begin{array}{l}-0.038^{* * *} \\
{[0.004]}\end{array}$ \\
\hline SOS & $\begin{array}{l}0.045^{* * *} \\
{[0.017]}\end{array}$ & $\begin{array}{l}0.061 * * * \\
{[0.022]}\end{array}$ & $\begin{array}{l}-0.106^{* * *} \\
{[0.026]}\end{array}$ & $\begin{array}{l}0.036^{* *} \\
{[0.017]}\end{array}$ & $\begin{array}{l}0.060 * * * \\
{[0.022]}\end{array}$ & $\begin{array}{l}-0.096 * * * \\
{[0.027]}\end{array}$ & $\begin{array}{l}0.044^{* *} \\
{[0.017]}\end{array}$ & $\begin{array}{l}0.040^{*} \\
{[0.022]}\end{array}$ & $\begin{array}{l}-0.084 * * * \\
{[0.027]}\end{array}$ \\
\hline MOS & $\begin{array}{l}0.030 * * * \\
{[0.009]}\end{array}$ & $\begin{array}{l}0.074 * * * \\
{[0.011]}\end{array}$ & $\begin{array}{l}-0.104^{* * *} \\
{[0.013]}\end{array}$ & $\begin{array}{l}0.021 * * \\
{[0.010]}\end{array}$ & $\begin{array}{l}0.074 * * * \\
{[0.012]}\end{array}$ & $\begin{array}{l}-0.095 * * * \\
{[0.015]}\end{array}$ & $\begin{array}{l}0.041 * * * \\
{[0.009]}\end{array}$ & $\begin{array}{l}0.074 * * * \\
{[0.011]}\end{array}$ & $\begin{array}{l}-0.115^{* * *} \\
{[0.013]}\end{array}$ \\
\hline ICT & $\begin{array}{l}0.035^{* * *} \\
{[0.009]}\end{array}$ & $\begin{array}{l}0.031 \text { *** } \\
{[0.011]}\end{array}$ & $\begin{array}{l}-0.066^{* * *} \\
{[0.014]}\end{array}$ & $\begin{array}{l}0.023^{* *} \\
{[0.011]}\end{array}$ & $\begin{array}{l}0.022 \\
{[0.014]}\end{array}$ & $\begin{array}{l}-0.045^{* * *} \\
{[0.017]}\end{array}$ & $\begin{array}{l}0.021 * * \\
{[0.009]}\end{array}$ & $\begin{array}{l}0.013 \\
{[0.011]}\end{array}$ & $\begin{array}{l}-0.034^{* *} \\
{[0.014]}\end{array}$ \\
\hline $\ln$ OPEN & $\begin{array}{l}0.034 * * * \\
{[0.006]}\end{array}$ & $\begin{array}{l}0.038 * * * \\
{[0.007]}\end{array}$ & $\begin{array}{l}-0.072^{* * *} \\
{[0.009]}\end{array}$ & & & & & & \\
\hline ln UNMEMB & & & & $\begin{array}{l}-0.006 \\
{[0.008]}\end{array}$ & $\begin{array}{l}-0.025^{* *} \\
{[0.010]}\end{array}$ & $\begin{array}{l}0.030 * * \\
{[0.012]}\end{array}$ & & & \\
\hline ln MATINT & & & & & & & $\begin{array}{l}0.008 * * * \\
{[0.002]}\end{array}$ & $\begin{array}{l}0.011^{* * *} \\
{[0.003]}\end{array}$ & $\begin{array}{l}-0.018^{* * *} \\
{[0.004]}\end{array}$ \\
\hline ln SERVINT & & & & & & & $\begin{array}{l}-0.020 * * * \\
{[0.002]}\end{array}$ & $\begin{array}{l}-0.013^{* * *} \\
{[0.003]}\end{array}$ & $\begin{array}{l}0.033 * * * \\
{[0.003]}\end{array}$ \\
\hline $\ln \mathrm{Y}$ & $\begin{array}{l}0.040 * * * \\
{[0.003]}\end{array}$ & $\begin{array}{l}-0.015 * * * \\
{[0.004]}\end{array}$ & $\begin{array}{l}-0.025^{* * *} \\
{[0.005]}\end{array}$ & $\begin{array}{l}0.028 * * * \\
{[0.004]}\end{array}$ & $\begin{array}{l}-0.009 * \\
{[0.005]}\end{array}$ & $\begin{array}{l}-0.019 * * * \\
{[0.006]}\end{array}$ & $\begin{array}{l}0.046^{* * * *} \\
{[0.003]}\end{array}$ & $\begin{array}{l}-0.012 * * * \\
{[0.004]}\end{array}$ & $\begin{array}{l}-0.033^{* * *} \\
{[0.005]}\end{array}$ \\
\hline $\ln \mathrm{K}$ & $\begin{array}{l}-0.002 * \\
{[0.001]}\end{array}$ & $\begin{array}{l}0.005^{* * *} \\
{[0.002]}\end{array}$ & $\begin{array}{l}-0.003 \\
{[0.002]}\end{array}$ & $\begin{array}{l}0.000 \\
{[0.001]}\end{array}$ & $\begin{array}{l}0.003 * \\
{[0.002]}\end{array}$ & $\begin{array}{l}-0.003 \\
{[0.002]}\end{array}$ & $\begin{array}{l}-0.002 * \\
{[0.001]}\end{array}$ & $\begin{array}{l}0.004^{* * *} \\
{[0.002]}\end{array}$ & $\begin{array}{l}-0.002 \\
{[0.002]}\end{array}$ \\
\hline Own-wage elasticity & $\begin{array}{l}0.042 \\
{[0.030]}\end{array}$ & $\begin{array}{l}-0.168^{* * *} \\
{[0.010]}\end{array}$ & $\begin{array}{l}-0.981 * * * \\
{[0.021]}\end{array}$ & $\begin{array}{l}-0.057 \\
{[0.036]}\end{array}$ & $\begin{array}{l}-0.196 * * * \\
{[0.013]}\end{array}$ & $\begin{array}{l}-1.020^{* * *} \\
{[0.027]}\end{array}$ & $\begin{array}{l}0.041 \\
{[0.030]}\end{array}$ & $\begin{array}{l}-0.171^{* * *} \\
{[0.010]}\end{array}$ & $\begin{array}{l}-0.967 * * * \\
{[0.021]}\end{array}$ \\
\hline$p$-value $\mathrm{H}_{0}: \beta_{\mathrm{SOS}}=\beta_{\mathrm{MOS}}$ & 0.46 & 0.61 & 0.94 & 0.49 & 0.62 & 0.97 & 0.88 & 0.19 & 0.33 \\
\hline Obs. & & 2357 & & & 1702 & & & 2348 & \\
\hline Generalized $\mathrm{R}^{2}$ & & 0.86 & & & 0.94 & & & 0.86 & \\
\hline & d) Adding & abor Produc & vity & e) Adding $E$ & $\overline{\text { nergy Prices }}$ & & $\begin{array}{l}\text { f) Adding } \\
\text { Time Effec }\end{array}$ & untry-Time & Ind Industry- \\
\hline & $\mathrm{H}$ & M & $\mathrm{L}$ & $\mathrm{H}$ & M & $\mathrm{L}$ & $\mathrm{H}$ & M & $\mathrm{L}$ \\
\hline $\ln \mathrm{W}^{\mathrm{H}}$ & $\begin{array}{l}0.133^{* * *} \\
{[0.005]}\end{array}$ & $\begin{array}{l}-0.151^{* * *} \\
{[0.005]}\end{array}$ & $\begin{array}{l}0.018 * * * \\
{[0.003]}\end{array}$ & $\begin{array}{l}0.130 * * * \\
{[0.005]}\end{array}$ & $\begin{array}{l}-0.146^{* * *} \\
{[0.005]}\end{array}$ & $\begin{array}{l}0.015^{* * *} \\
{[0.003]}\end{array}$ & $\begin{array}{l}0.143^{* * * *} \\
{[0.004]}\end{array}$ & $\begin{array}{l}-0.127 * * * \\
{[0.005]}\end{array}$ & $\begin{array}{l}-0.016^{* * *} \\
{[0.003]}\end{array}$ \\
\hline $\ln \mathrm{W}^{\mathrm{M}}$ & $\begin{array}{l}-0.151^{* * *} \\
{[0.005]}\end{array}$ & $\begin{array}{l}0.123^{* * *} \\
{[0.006]}\end{array}$ & $\begin{array}{l}0.028 * * * \\
{[0.004]}\end{array}$ & $\begin{array}{l}-0.146^{* * *} \\
{[0.005]}\end{array}$ & $\begin{array}{l}0.119 * * * \\
{[0.006]}\end{array}$ & $\begin{array}{l}0.027 * * * \\
{[0.004]}\end{array}$ & $\begin{array}{l}-0.127 * * * \\
{[0.005]}\end{array}$ & $\begin{array}{l}0.136 * * * \\
{[0.007]}\end{array}$ & $\begin{array}{l}-0.008^{* *} \\
{[0.004]}\end{array}$ \\
\hline $\ln \mathrm{W}^{\mathrm{L}}$ & $\begin{array}{l}0.018^{* * *} \\
{[0.003]}\end{array}$ & $\begin{array}{l}0.028 * * * \\
{[0.004]}\end{array}$ & $\begin{array}{l}-0.045^{* * * *} \\
{[0.004]}\end{array}$ & $\begin{array}{l}0.015^{* * * *} \\
{[0.003]}\end{array}$ & $\begin{array}{l}0.027 * * * \\
{[0.004]}\end{array}$ & $\begin{array}{l}-0.043^{* * *} \\
{[0.004]}\end{array}$ & $\begin{array}{l}-0.016^{* * *} \\
{[0.003]}\end{array}$ & $\begin{array}{l}-0.008^{* *} \\
{[0.004]}\end{array}$ & $\begin{array}{l}0.025^{* * * *} \\
{[0.004]}\end{array}$ \\
\hline SOS & $\begin{array}{l}0.036^{* *} \\
{[0.017]}\end{array}$ & $\begin{array}{l}0.054 * * \\
{[0.022]}\end{array}$ & $\begin{array}{l}-0.090^{* * *} \\
{[0.027]}\end{array}$ & $\begin{array}{l}0.036^{* *} \\
{[0.017]}\end{array}$ & $\begin{array}{l}0.072 * * * \\
{[0.022]}\end{array}$ & $\begin{array}{l}-0.108^{* * *} \\
{[0.027]}\end{array}$ & $\begin{array}{l}0.044 * * \\
{[0.022]}\end{array}$ & $\begin{array}{l}0.070 * * * \\
{[0.022]}\end{array}$ & $\begin{array}{l}-0.114^{* * *} \\
{[0.025]}\end{array}$ \\
\hline MOS & $\begin{array}{l}0.048^{* * *} \\
{[0.009]}\end{array}$ & $\begin{array}{l}0.086^{* * *} \\
{[0.011]}\end{array}$ & $\begin{array}{l}-0.134^{* * *} \\
{[0.014]}\end{array}$ & $\begin{array}{l}0.037 * * * \\
{[0.009]}\end{array}$ & $\begin{array}{l}0.077 * * * \\
{[0.011]}\end{array}$ & $\begin{array}{l}-0.114^{* * *} \\
{[0.014]}\end{array}$ & $\begin{array}{l}0.012 \\
{[0.009]}\end{array}$ & $\begin{array}{l}0.038 * * * \\
{[0.009]}\end{array}$ & $\begin{array}{l}-0.050 * * * \\
{[0.010]}\end{array}$ \\
\hline ICT & $\begin{array}{l}0.027^{* * *} \\
{[0.009]}\end{array}$ & $\begin{array}{l}0.020 * \\
{[0.011]}\end{array}$ & $\begin{array}{l}-0.048^{* * *} \\
{[0.014]}\end{array}$ & $\begin{array}{l}0.023 * * * \\
{[0.009]}\end{array}$ & $\begin{array}{l}0.020 * \\
{[0.011]}\end{array}$ & $\begin{array}{l}-0.043^{* * *} \\
{[0.014]}\end{array}$ & $\begin{array}{l}0.011 \\
{[0.009]}\end{array}$ & $\begin{array}{l}0.008 \\
{[0.009]}\end{array}$ & $\begin{array}{l}-0.020 * * \\
{[0.010]}\end{array}$ \\
\hline In LABPROD & $\begin{array}{l}-0.012 * * * \\
{[0.002]}\end{array}$ & $\begin{array}{l}-0.005^{*} \\
{[0.003]}\end{array}$ & $\begin{array}{l}0.017 * * * \\
{[0.003]}\end{array}$ & & & & & & \\
\hline ln PEN & & & & $\begin{array}{l}0.006^{* *} \\
{[0.002]}\end{array}$ & $\begin{array}{l}-0.020^{* * *} \\
{[0.003]}\end{array}$ & $\begin{array}{l}0.014 * * * \\
{[0.004]}\end{array}$ & & & \\
\hline $\ln \mathrm{Y}$ & $\begin{array}{l}0.046 * * * \\
{[0.004]}\end{array}$ & $\begin{array}{l}-0.013 * * * \\
{[0.004]}\end{array}$ & $\begin{array}{l}-0.034^{* * *} \\
{[0.005]}\end{array}$ & $\begin{array}{l}0.040 * * * \\
{[0.003]}\end{array}$ & $\begin{array}{l}-0.017 * * * \\
{[0.004]}\end{array}$ & $\begin{array}{l}-0.022 * * * \\
{[0.005]}\end{array}$ & $\begin{array}{l}0.017 * * * \\
{[0.004]}\end{array}$ & $\begin{array}{l}0.011 * * * \\
{[0.004]}\end{array}$ & $\begin{array}{l}-0.028 * * * \\
{[0.004]}\end{array}$ \\
\hline $\ln \mathrm{K}$ & $\begin{array}{l}-0.001 \\
{[0.001]}\end{array}$ & $\begin{array}{l}0.006^{* * * *} \\
{[0.002]}\end{array}$ & $\begin{array}{l}-0.005^{* * *} \\
{[0.002]}\end{array}$ & $\begin{array}{l}-0.002 \\
{[0.001]}\end{array}$ & $\begin{array}{l}0.006^{* * *} \\
{[0.002]}\end{array}$ & $\begin{array}{l}-0.004^{* *} \\
{[0.002]}\end{array}$ & $\begin{array}{l}0.001 \\
{[0.001]}\end{array}$ & $\begin{array}{l}0.005^{* * *} \\
{[0.001]}\end{array}$ & $\begin{array}{l}-0.006^{* * *} \\
{[0.001]}\end{array}$ \\
\hline Own-wage elasticity & $\begin{array}{l}0.038 \\
{[0.030]}\end{array}$ & $\begin{array}{l}-0.169 * * * \\
{[0.010]}\end{array}$ & $\begin{array}{l}-1.002^{* * *} \\
{[0.021]}\end{array}$ & $\begin{array}{l}0.017 \\
{[0.030]}\end{array}$ & $\begin{array}{l}-0.176^{* * *} \\
{[0.010]}\end{array}$ & $\begin{array}{l}-0.988 * * * \\
{[0.021]}\end{array}$ & $\begin{array}{l}0.105^{* * *} \\
{[0.029]}\end{array}$ & $\begin{array}{l}-0.150^{* * *} \\
{[0.010]}\end{array}$ & $\begin{array}{l}-0.672 * * * \\
{[0.018]}\end{array}$ \\
\hline$p$-value $\mathrm{H}_{0}: \beta_{\mathrm{SOS}}=\beta_{\mathrm{MOS}}$ & 0.56 & 0.22 & 0.17 & 0.95 & 0.85 & 0.85 & 0.20 & 0.22 & 0.03 \\
\hline Obs. & & 2357 & & & 2357 & & & 2357 & \\
\hline Generalized $\mathrm{R}^{2}$ & & 0.85 & & & 0.85 & & & 0.95 & \\
\hline
\end{tabular}


Table 6 - Relaxing the Model's Assumptions

Dependent Variables: Wage Bill Shares, Unless Otherwise Indicated

\begin{tabular}{|c|c|c|c|c|c|c|c|c|c|}
\hline & $\mathrm{H}$ & $\mathrm{M}$ & $\mathrm{L}$ & $\mathrm{H}$ & $\mathrm{M}$ & $\mathrm{L}$ & $\mathrm{H}$ & $\mathrm{M}$ & $\mathrm{L}$ \\
\hline & \multicolumn{9}{|c|}{ Issue: Construction of the Offshoring Proxies } \\
\hline & \multicolumn{3}{|c|}{ a) SOS_Y and MOS_Y } & \multicolumn{3}{|c|}{ b) SOS_9500 and MOS_9500 } & \multicolumn{3}{|c|}{ c) SOS_OFF and MOS_OFF } \\
\hline \multirow[t]{2}{*}{ Service Offshoring } & $0.122 * * *$ & 0.054 & $-0.176^{* *}$ & $0.046^{*}$ & $0.080 * *$ & $-0.126 * * *$ & $0.234^{*}$ & $0.365 * *$ & $-0.600 * * *$ \\
\hline & {$[0.045]$} & {$[0.057]$} & {$[0.071]$} & {$[0.026]$} & {$[0.033]$} & {$[0.040]$} & [0.140] & {$[0.166]$} & {$[0.214]$} \\
\hline \multirow[t]{2}{*}{ Material Offshoring } & $0.073 * * *$ & $0.133^{* * *}$ & $-0.206 * * *$ & $0.095 * * *$ & $0.127^{* * *}$ & $-0.221 * * *$ & $0.062 * * *$ & $0.093 * * *$ & $-0.156^{* * *}$ \\
\hline & {$[0.017]$} & {$[0.021]$} & {$[0.026]$} & {$[0.011]$} & {$[0.014]$} & {$[0.017]$} & {$[0.022]$} & {$[0.026]$} & {$[0.034]$} \\
\hline \multirow[t]{2}{*}{ ICT } & $0.023 * * *$ & $0.019 *$ & $-0.043 * * *$ & $0.027 * * *$ & $0.026 * *$ & $-0.053 * * *$ & $0.041^{* *}$ & $0.063 * * *$ & $-0.104 * * *$ \\
\hline & [0.009] & [0.011] & {$[0.014]$} & {$[0.009]$} & {$[0.011]$} & {$[0.013]$} & [0.019] & {$[0.022]$} & [0.029] \\
\hline$p$-value $\mathrm{H}_{0}: \beta_{\mathrm{SOS}}=\beta_{\mathrm{MOS}}$ & 0.32 & 0.21 & 0.70 & 0.10 & 0.20 & 0.03 & 0.24 & 0.12 & 0.05 \\
\hline Obs. & & 2357 & & & 2479 & & & 335 & \\
\hline \multirow[t]{3}{*}{ Generalized $\mathrm{R}^{2}$} & & 0.85 & & & 0.85 & & & 0.73 & \\
\hline & \multicolumn{9}{|c|}{ Issue: Wage Rigidities } \\
\hline & \multicolumn{3}{|c|}{ d) Employment Shares as the Dep. Var. } & \multicolumn{3}{|c|}{ e) Country-Level Wages } & \multicolumn{3}{|c|}{ f) Excluding Wages } \\
\hline \multirow[t]{2}{*}{ SOS } & $0.043 * * *$ & $0.041^{*}$ & $-0.084 * * *$ & $0.065 * * *$ & $0.040 *$ & $-0.105^{* * *}$ & $0.053 * * *$ & 0.035 & $-0.089 * * *$ \\
\hline & [0.013] & {$[0.022]$} & {$[0.025]$} & [0.019] & [0.024] & {$[0.025]$} & [0.019] & [0.024] & {$[0.027]$} \\
\hline \multirow[t]{2}{*}{ MOS } & $0.023 * * *$ & $0.076^{* * *}$ & $-0.099 * * *$ & $0.022^{* *}$ & $0.074 * * *$ & $-0.096 * * *$ & $0.033 * * *$ & $0.093 * * *$ & $-0.126 * * *$ \\
\hline & {$[0.007]$} & {$[0.011]$} & {$[0.013]$} & {$[0.010]$} & [0.012] & {$[0.013]$} & {$[0.010]$} & [0.012] & {$[0.014]$} \\
\hline \multirow[t]{2}{*}{ ICT } & $0.012^{*}$ & $0.045^{* * *}$ & $-0.056 * * *$ & $0.016^{*}$ & 0.018 & $-0.034 * * *$ & $0.016^{*}$ & $0.029 * *$ & $-0.045 * * *$ \\
\hline & [0.007] & {$[0.011]$} & [0.013] & {$[0.010]$} & [0.012] & [0.013] & {$[0.010]$} & [0.013] & [0.014] \\
\hline$p$-value $\mathrm{H}_{0}: \beta_{\mathrm{SOS}}=\beta_{\mathrm{MOS}}$ & 0.21 & 0.17 & 0.62 & 0.06 & 0.23 & 0.76 & 0.37 & 0.05 & 0.25 \\
\hline Obs. & & 2357 & & & 2357 & & & 2357 & \\
\hline Generalized $\mathrm{R}^{2}$ & & 0.81 & & & 0.81 & & & 0.78 & \\
\hline
\end{tabular}

\begin{tabular}{|c|c|c|c|c|c|c|c|c|c|}
\hline \multirow[b]{3}{*}{ sos } & \multicolumn{9}{|c|}{ Issue: Labor Supply Shifts } \\
\hline & \multicolumn{3}{|c|}{ g) Adding Growth in Hours Worked ( $\Delta E$ ) } & \multicolumn{3}{|c|}{ h) Adding Growth in $\operatorname{Esh}^{H}\left(\Delta E s h^{H}\right)$} & \multicolumn{3}{|c|}{ i) Country- and Ind.-Spec. Time Trends } \\
\hline & $\begin{array}{l}0.038^{* *} \\
{[0.017]}\end{array}$ & $\begin{array}{l}0.051^{* *} \\
{[0.022]}\end{array}$ & $\begin{array}{l}-0.089 * * * \\
{[0.027]}\end{array}$ & $\begin{array}{l}0.055^{* * *} \\
{[0.017]}\end{array}$ & $\begin{array}{l}0.049 * * \\
{[0.022]}\end{array}$ & $\begin{array}{l}-0.105^{* * *} \\
{[0.027]}\end{array}$ & $\begin{array}{l}0.037 * * \\
{[0.017]}\end{array}$ & $\begin{array}{l}0.050^{* *} \\
{[0.021]}\end{array}$ & $\begin{array}{l}-0.088^{* * *} \\
{[0.025]}\end{array}$ \\
\hline MOS & $\begin{array}{l}0.037 * * * \\
{[0.009]}\end{array}$ & $\begin{array}{l}0.082 * * * \\
{[0.011]}\end{array}$ & $\begin{array}{l}-0.119 * * * \\
{[0.013]}\end{array}$ & $\begin{array}{l}0.029 * * * \\
{[0.008]}\end{array}$ & $\begin{array}{l}0.081 * * * \\
{[0.011]}\end{array}$ & $\begin{array}{l}-0.110^{* * *} \\
{[0.014]}\end{array}$ & $\begin{array}{l}0.026^{* * *} \\
{[0.009]}\end{array}$ & $\begin{array}{l}0.072 * * * \\
{[0.011]}\end{array}$ & $\begin{array}{l}-0.099 * * * \\
{[0.013]}\end{array}$ \\
\hline ICT & $\begin{array}{l}0.023^{* * *} \\
{[0.009]}\end{array}$ & $\begin{array}{l}0.019 * \\
{[0.011]}\end{array}$ & $\begin{array}{l}-0.042^{* * *} \\
{[0.014]}\end{array}$ & $\begin{array}{l}0.024^{* * *} \\
{[0.009]}\end{array}$ & $\begin{array}{l}0.016 \\
{[0.011]}\end{array}$ & $\begin{array}{l}-0.040^{* * *} \\
{[0.014]}\end{array}$ & $\begin{array}{l}0.018 * * \\
{[0.009]}\end{array}$ & $\begin{array}{l}0.008 \\
{[0.011]}\end{array}$ & $\begin{array}{l}-0.026^{* *} \\
{[0.013]}\end{array}$ \\
\hline$p$-value $\mathrm{H}_{0}: \beta_{\text {SOS }}=\beta_{\text {MOS }}$ & 0.97 & 0.23 & 0.34 & 0.20 & 0.22 & 0.86 & 0.59 & 0.38 & 0.71 \\
\hline Obs. & & 2357 & & & 2319 & & & 2357 & \\
\hline \multirow[t]{3}{*}{ Generalized $\mathrm{R}^{2}$} & & 0.86 & & & 0.87 & & & 0.88 & \\
\hline & \multicolumn{9}{|c|}{ Issue: Simultaneity } \\
\hline & \multicolumn{3}{|c|}{ j) Instrumenting SOS } & \multicolumn{3}{|c|}{ k) Instrumenting All the Shift-Factors } & \multicolumn{3}{|c|}{ l) Instrumenting All the Expl. Var. } \\
\hline sos & $\begin{array}{l}0.060^{* *} \\
{[0.028]}\end{array}$ & $\begin{array}{l}0.073 * * \\
{[0.034]}\end{array}$ & $\begin{array}{l}-0.133^{* * *} \\
{[0.043]}\end{array}$ & $\begin{array}{l}0.057 * * \\
{[0.027]}\end{array}$ & $\begin{array}{l}0.066^{*} \\
{[0.034]}\end{array}$ & $\begin{array}{l}-0.123^{* * *} \\
{[0.042]}\end{array}$ & $\begin{array}{l}0.060^{* *} \\
{[0.027]}\end{array}$ & $\begin{array}{l}0.069 * * \\
{[0.034]}\end{array}$ & $\begin{array}{l}-0.128 * * * \\
{[0.042]}\end{array}$ \\
\hline MOS & $\begin{array}{l}0.035 * * * \\
{[0.009]}\end{array}$ & $\begin{array}{l}0.080^{* * *} \\
{[0.011]}\end{array}$ & $\begin{array}{l}-0.114 * * * \\
{[0.014]}\end{array}$ & $\begin{array}{l}0.039 * * * \\
{[0.013]}\end{array}$ & $\begin{array}{l}0.115^{* * *} \\
{[0.016]}\end{array}$ & $\begin{array}{l}-0.153^{* * *} \\
{[0.020]}\end{array}$ & $\begin{array}{l}0.038^{* * *} \\
{[0.013]}\end{array}$ & $\begin{array}{l}0.110^{* * *} \\
{[0.016]}\end{array}$ & $\begin{array}{l}-0.148^{* * * *} \\
{[0.020]}\end{array}$ \\
\hline ICT & $\begin{array}{l}0.023^{* * *} \\
{[0.009]}\end{array}$ & $\begin{array}{l}0.019^{*} \\
{[0.011]}\end{array}$ & $\begin{array}{l}-0.042^{* * *} \\
{[0.014]}\end{array}$ & $\begin{array}{l}0.043^{* * *} \\
{[0.015]}\end{array}$ & $\begin{array}{l}-0.012 \\
{[0.019]}\end{array}$ & $\begin{array}{l}-0.031 \\
{[0.024]}\end{array}$ & $\begin{array}{l}0.029 * * \\
{[0.013]}\end{array}$ & $\begin{array}{l}0.004 \\
{[0.017]}\end{array}$ & $\begin{array}{l}-0.033 \\
{[0.021]}\end{array}$ \\
\hline$p$-value $\mathrm{H}_{0}: \beta_{\mathrm{SOS}}=\beta_{\mathrm{MOS}}$ & 0.41 & 0.86 & 0.70 & 0.55 & 0.21 & 0.53 & 0.49 & 0.29 & 0.68 \\
\hline Obs. & & 2357 & & & 2357 & & & 2357 & \\
\hline Generalized $\mathrm{R}^{2}$ & & 0.85 & & & 0.85 & & & 0.85 & \\
\hline \multicolumn{10}{|l|}{ IV Statistics } \\
\hline Hansen $J$ & & 1.09 & & & 3.62 & & & 17.11 & \\
\hline Hansen $J$ ( $p$-value) & & 0.30 & & & 0.31 & & & 0.02 & \\
\hline Cragg-Donald & & 76.7 & & & 27.6 & & & 29.3 & \\
\hline$F$-stat. Excl. Ins. (min-max) & & 76.7 & & & $30.4-46.9$ & & & $16.2-451.0$ & \\
\hline Shea Partial R ${ }^{2}$ (min-max) & & 0.4 & & & $0.3-0.5$ & & & $0.4-0.7$ & \\
\hline
\end{tabular}


Table 7 - Economic Magnitude

\begin{tabular}{lccc}
\hline \hline & $\mathrm{H}$ & $\mathrm{M}$ & $\mathrm{L}$ \\
\cline { 2 - 4 } SOS & $0.9^{* *}$ & $11.2^{* * *}$ & $3.3^{* * *}$ \\
& {$[0.4]$} & {$[4.3]$} & {$[0.9]$} \\
MOS & $1.2^{* * *}$ & $21.3^{* * *}$ & $5.3^{* * *}$ \\
& {$[0.3]$} & {$[2.9]$} & {$[0.6]$} \\
ICT & $0.8^{* * *}$ & $5.1^{*}$ & $2.0^{* * *}$ \\
& {$[0.3]$} & {$[3.0]$} & {$[0.6]$} \\
\hline The table reports the percentage contribution of each shift-factor to the observed changes in the three \\
wage bill shares over the sample period. The contributions are computed multiplying the coefficients \\
reported in panel d) of Table 4 by the changes in the shift-factors between 1990 and 2004 (shown in \\
Table 2 for SOS and MOS and equal to 17.9 percent for ICT) and then dividing the resulting numbers by \\
the changes in the wage bill shares reported in Table 3. The standard errors (reported in square brackets) \\
are computed using the delta method. See also notes to previous tables.
\end{tabular}


Table 8 - Comparing the Contributions with Feenstra and Hanson's (1999)

Dependent Variable: Wage Bill Share of High Skilled Workers plus Medium Skilled Workers $\left(W S H^{S}\right)$

\begin{tabular}{|c|c|c|c|c|c|}
\hline & Estimates & Contributions (\%) & $\begin{array}{l}\text { Estimates - No } \\
\text { SOS }\end{array}$ & $\begin{array}{c}\text { Contributions (\%) - No } \\
\text { SOS }\end{array}$ & $\begin{array}{c}\text { Contributions (\%) - Feenstra } \\
\text { and Hanson }\end{array}$ \\
\hline & (1) & (2) & $\begin{array}{c}(3) \\
\end{array}$ & $\begin{array}{c}(4) \\
\end{array}$ & $\begin{array}{c}\text { (5) } \\
\end{array}$ \\
\hline $\ln W^{S}$ & $\begin{array}{c}-0.038 * * * \\
{[0.004]}\end{array}$ & & $\begin{array}{c}-0.039 * * * \\
{[0.004]}\end{array}$ & & \\
\hline sos & $\begin{array}{c}0.094 * * * \\
{[0.022]}\end{array}$ & $\begin{array}{c}8.6 * * * \\
{[2.1]}\end{array}$ & & & \\
\hline MOS & $\begin{array}{c}0.118 * * * \\
{[0.017]}\end{array}$ & $\begin{array}{c}14.3^{* * *} \\
{[2.0]}\end{array}$ & $\begin{array}{c}0.123^{* * *} \\
{[0.016]}\end{array}$ & $\begin{array}{c}14.9^{* * *} \\
{[2.0]}\end{array}$ & 14.0 \\
\hline ICT & $\begin{array}{c}0.044 * * * \\
{[0.014]}\end{array}$ & $\begin{array}{c}5.4^{* * *} \\
{[1.7]}\end{array}$ & $\begin{array}{c}0.043^{* * *} \\
{[0.014]}\end{array}$ & $\begin{array}{c}5.2 * * * \\
{[1.7]}\end{array}$ & 5.3 \\
\hline $\ln \mathrm{Y}$ & $\begin{array}{c}0.023 * * * \\
{[0.005]}\end{array}$ & & $\begin{array}{c}0.024 * * * \\
{[0.005]}\end{array}$ & & \\
\hline $\ln \mathrm{K}$ & $\begin{array}{l}0.004 * \\
{[0.002]}\end{array}$ & & $\begin{array}{l}0.004 * \\
{[0.002]}\end{array}$ & & \\
\hline Own-wage elasticity & $\begin{array}{c}-0.261^{* * *} \\
{[0.005]}\end{array}$ & & $\begin{array}{c}-0.261^{* * *} \\
{[0.005]}\end{array}$ & & \\
\hline$p$-value $\mathrm{H}_{0}: \beta_{\mathrm{sOS}}=\beta_{\mathrm{MOS}}$ & 0.41 & & - & & \\
\hline Obs. & 2357 & & 2409 & & \\
\hline $\mathrm{R}^{2}$ & 0.61 & & 0.61 & & \\
\hline
\end{tabular}


Table A1 - Variables and Descriptive Statistics

\begin{tabular}{|c|c|c|c|c|c|c|}
\hline Name & Definition & \multicolumn{2}{|l|}{ Source } & Obs. & Mean & Std. Dev. \\
\hline $\mathrm{Wsh}^{\mathrm{H}}$ & Wage bill share of high skilled workers & \multicolumn{2}{|c|}{ EUKLEMS } & 2680 & 15.0 & 12.0 \\
\hline $\mathrm{Wsh}^{\mathrm{M}}$ & Wage bill share of medium skilled workers & \multicolumn{2}{|c|}{ EUKLEMS } & 2680 & 63.8 & 19.9 \\
\hline $\mathrm{Wsh}^{\mathrm{L}}$ & Wage bill share of low skilled workers & \multicolumn{2}{|c|}{ EUKLEMS } & 2680 & 21.2 & 15.6 \\
\hline $\mathrm{Wsh}^{\mathrm{S}}$ & Wage bill share of high skilled plus medium skilled workers & \multicolumn{2}{|c|}{ EUKLEMS } & 2680 & 78.8 & 15.6 \\
\hline $\operatorname{Esh}^{\mathrm{H}}$ & Employment share of high skilled workers & \multicolumn{2}{|c|}{ EUKLEMS } & 2680 & 9.8 & 8.8 \\
\hline $\operatorname{Esh}^{\mathrm{M}}$ & Employment share of medium skilled workers & \multicolumn{2}{|c|}{ EUKLEMS } & 2680 & 63.9 & 19.1 \\
\hline $\operatorname{Esh}^{\mathrm{L}}$ & Employment share of low skilled workers & \multicolumn{2}{|c|}{ EUKLEMS } & 2680 & 26.3 & 17.0 \\
\hline $\ln \mathrm{W}^{\mathrm{H}}$ & Log real hourly wage of high skilled workers & \multicolumn{2}{|c|}{ EUKLEMS } & 2680 & 3.3 & 0.8 \\
\hline $\ln \mathrm{W}^{\mathrm{M}}$ & Log real hourly wage of medium skilled workers & \multicolumn{2}{|c|}{ EUKLEMS } & 2680 & 2.8 & 0.8 \\
\hline $\ln \mathrm{W}^{\mathrm{L}}$ & Log real hourly wage of low skilled workers & \multicolumn{2}{|c|}{ EUKLEMS } & 2680 & 2.5 & 0.8 \\
\hline $\ln \mathrm{W}^{\mathrm{S}}$ & Log real hourly wage of high skilled plus medium skilled workers & \multicolumn{2}{|c|}{ EUKLEMS } & 2680 & 2.9 & 0.8 \\
\hline $\ln \mathrm{W}^{\mathrm{H}}$, country-level & Log real hourly wage of high skilled workers (country average) & \multicolumn{2}{|c|}{ EUKLEMS } & 2680 & 3.3 & 0.7 \\
\hline $\ln \mathrm{W}^{\mathrm{M}}$, country-level & Log real hourly wage of medium skilled workers (country average) & \multicolumn{2}{|c|}{ EUKLEMS } & 2680 & 2.8 & 0.7 \\
\hline $\ln \mathrm{W}^{\mathrm{L}}$, country-level & Log real hourly wage of low skilled workers (country average) & \multicolumn{2}{|c|}{ EUKLEMS } & 2680 & 2.5 & 0.7 \\
\hline $\ln \mathrm{Y}$ & Log output & \multicolumn{2}{|c|}{ EUKLEMS } & 2700 & 9.8 & 1.6 \\
\hline $\ln \mathrm{K}$ & Log capital investment & \multicolumn{2}{|c|}{ EUKLEMS } & 2659 & 7.7 & 1.8 \\
\hline SOS & $\begin{array}{l}\text { Service offshoring (share of imported private services in total non- } \\
\text { energy input purchases) }\end{array}$ & \multicolumn{2}{|c|}{ Eurostat and EUKLEMS } & 2403 & 3.0 & 5.1 \\
\hline SOS_Y & Service offshoring normalized by industry output & \multicolumn{2}{|c|}{ Eurostat and EUKLEMS } & 2405 & 1.4 & 2.1 \\
\hline SOS_9500 & $\begin{array}{l}\text { Service offshoring based on Import Matrix coefficients for } 1995 \text { and } \\
2000\end{array}$ & \multicolumn{2}{|c|}{ Eurostat and EUKLEMS } & 2528 & 2.1 & 3.4 \\
\hline SOS_OFF & Service offshoring based on official import data & \multicolumn{2}{|c|}{ Eurostat and EUKLEMS } & 338 & 2.0 & 2.5 \\
\hline MOS & $\begin{array}{l}\text { Material offshoring (share of imported intermediate inputs in total non } \\
\text { energy input purchases) }\end{array}$ & $\begin{array}{l}\text { Eurostat, } \\
\text { OECD }\end{array}$ & EUKLEMS and & 2458 & 22.1 & 19.3 \\
\hline MOS_Y & Material offshoring normalized by industry output & $\begin{array}{l}\text { Eurostat, } \\
\text { OECD }\end{array}$ & EUKLEMS and & 2514 & 12.6 & 12.2 \\
\hline MOS_9500 & $\begin{array}{l}\text { Material offshoring based on Import Matrix coefficients for } 1995 \text { and } \\
2000\end{array}$ & $\begin{array}{l}\text { Eurostat, } \\
\text { OECD }\end{array}$ & EUKLEMS and & 2579 & 19.9 & 17.8 \\
\hline MOS_OFF & Material offshoring based on official import data & $\begin{array}{l}\text { Eurostat, } \\
\text { OECD }\end{array}$ & EUKLEMS and & 339 & 19.1 & 14.9 \\
\hline ICT & $\begin{array}{l}\text { Share of information and communication technologies in total capital } \\
\text { investment }\end{array}$ & EUKLEN & & 2640 & 14.5 & 14.6 \\
\hline In SERVINT & Log total service purchases over total hours worked & EUKLEN & & 2473 & 2.6 & 1.0 \\
\hline ln MATINT & Log total material purchases over total hours worked & EUKLEN & & 2473 & 2.9 & 1.3 \\
\hline $\ln$ OPEN & Log imports plus exports over GDP (country-level) & World D & lopment Indicators & 2700 & -0.5 & 0.3 \\
\hline In UNMEMB & Log union members over total employment (country-level) & Nickell ( & & 1980 & -1.1 & 0.6 \\
\hline ln LABPROD & Log value added per hour worked & EUKLEN & & 2700 & 3.3 & 1.0 \\
\hline $\ln$ PEN & Log energy price & EUKLEN & & 2638 & 0.1 & 0.2 \\
\hline$\Delta \mathrm{E}$ & \% Change in total number of hours worked & EUKLEN & & 2700 & -0.5 & 4.9 \\
\hline$\Delta \operatorname{Esh}^{\mathrm{H}}$ & $\%$ Change in employment share of high skilled workers & EUKLEN & & 2660 & 4.7 & 10.9 \\
\hline
\end{tabular}

